ЛЮБОВНАЯ НОВЕЛЛИСТИКА В АВТОРСКОМ УЧЕБНО-БЕЛЛЕТРИСТИЧЕСКОМ ТЕКСТЕ ПРЕПОДАВАТЕЛЯ ДЛЯ ИНОСТРАННОЙ АУДИТОРИИ

DOI: $10.31618 /$ ESU.2413-9335.2020.1.71.582

Пузырева Ольга Григорьевна

Соискатель

Федерального государственного бюджетного образовательного учреждения высшего образования

«Государственный институт русского языка им. А.С. Пушкина»

\title{
LOVE STORIES IN THE AUTHOR'S EDUCATIONAL FICTION TEXT OF THE TEACHER FOR A FOREIGN AUDIENCE
}

\author{
Puzyreva Olga Grigoryevna \\ Applicant \\ of the Federal State Budget Educational Institution \\ of Higher Education \\ «Pushkin State Russian Language Institute»
}

\begin{abstract}
АННОТАЦИЯ
В статье описывается интерпретация темы любви в авторском учебно-беллетристическом тексте преподавателя для иностранной аудитории на уровне владения русским языком В1-С1 как ключевого ценностно-смыслового понятия русской ментально-языковой картины мира. Приводятся психологопедагогические, методические и философские аргументы необходимости включения данной темы в предлагаемый цикл новелл. Особое внимание уделяется тому, как речевой и «креативно-двигательный» (С.В. Дмитриев) диалог ситуации влюблённости взаимосвязан с окружающим социокультурным пространством.
\end{abstract}

\section{ABSTRACT}

The article describes the interpretation of the theme of love in the author's educational fiction text of the teacher for a foreign audience at the level of Russian language proficiency B1-C1 as a key value-semantic concept of the Russian mental-language picture of the world. The author presents psychological, pedagogical, methodological and philosophical arguments for the need to include this topic in the proposed cycle of short stories. Special attention is paid to how the speech and "creative-motor " (S. V. Dmitriev) dialogue of the situation of love is interconnected with the surrounding socio-cultural space.

Ключевые слова: авторский учебно-беллетристический текст преподавателя для иностранной аудитории; тема любви; ситуация влюблённости; философия русского Эроса; «философия сердца»; тема любви в русской литературе; речевой и «креативно-двигательный» диалог; социокультурное пространство.

Key words: the author's educational and fiction text of the teacher for a foreign audience; the theme of love; the situation of love; Russian Eros philosophy; «philosophy of the heart»; the theme of love in Russian literature; speech and "creative-motor" dialogue; socio-cultural space.

Данная статья продолжает цикл публикаций, в которых исследуются типологические дефиниции и методические аспекты авторского учебнобеллетристического текста преподавателя для иностранной аудитории на уровне владения русским языком В1-C1. В ней мы постараемся аргументировать необходимость включения в такой текст новелл с любовной тематикой; приведём примеры того, как данная тема художественно интерпретируется в четырёх новеллах нашего повествовательного цикла: «Ax, ты, окно, откройся!», «Первая любовь светла и грустна...», «Два снегопада», «Вид из окна, или Московская мелодия». В приложении к статье коллеги могут ознакомиться с текстом одной из новелл.

Несмотря на колоссальную модификациию жизненных приоритетов в современном мире, тема любви между мужчиной и женщиной, как и тысячи лет назад, продолжает волновать сердца и умы людей - обывателей, учёных, представителей творческой сферы.

Необходимость включения темы любви в наш учебно-беллетристический цикл связана прежде всего с психолого-педагогическими причинами и

Обусловлена самой жизненнокооммуникативной реальностью. Попытаемся вкратце её обозначить.

Иностранные учащиеся для автора данной статьи - это не только субъекты обучения и воспитания. Это представители той социальной группы, с которой в течение многих лет связана педагогическая профессия автора, составляющая для неё один из важнейших жизненных смыслов. Люди, принадлежащие к данной социальной группе, являются для автора статьи постоянным и доверительным кругом общения. Добавим, что это люди в большинстве своём очень молодые, - от шестнадцати до двадцати трёх лет. Как замечает исследователь В.В. Сутормин, интерес к противоположному полу в студенческом возрасте 
носит сложный характер, связан с многокомпонентным содержанием, различными фазами и разнообразной индивидуальноличностной мотивацией [10]. Иностранные студенты не являются здесь исключением. Среди них, как показывает многолетняя практика преподавания, всегда есть те, кто непосредственно в период обучения в нашем Институте переживает влюблённость. Кому-то из учащихся предстоит пережить это в будущем, а иные уже имеют подобный, нередко печальный опыт и связанную с ним душевную травму. Поскольку аудиторное общение учащихся с преподавателем по практике речи почти каждодневное и многочасовое, то ему трудно не заметить эмоциональнопсихологическое состояние того или иного учащегося. А они в большинстве своём видят в преподавателе практики ту «скорую помощь», куда нужно обратиться, оказавшись в сложных жизненных положениях. И здесь преподаватель старается сделать всё возможное, чтобы помочь своим подопечным, - вплоть до того, что сам отвозит их в больницу, если возникшая проблема связана со здоровьем; пытается поговорить с работниками общежития, чтобы уладить бытовые проблемы учащихся, и т.д. Бывает, что он оказывается также в курсе «сердечных дел» своих учащихся - по их собственной инициативе. В таких ситуациях, помимо приватной беседы после занятий, нам представляется целесообразным, чтобы непосредственно обучение также содержало приёмы и формы, способствующие позитивному движению эмоций и сознания учащихся, переживающих подобный жизненный этап. Одной из таких форм может быть чтение и обсуждение новелл с любовной тематикой, написанных автором-преподавателем. И даже если в жизни иностранные учащиеся ещё ни с чем подобным не сталкивались, интерес к теме любви в литературном творчестве, принимая во внимание их юный возраст, у них всё равно немалый. Впрочем, по мудрому замечанию А.С. Пушкина, «любви все возрасты покорны».

Новеллы о любви, как и все новеллы нашего цикла, содержат интертекстуальный материал, обращение к «облигаторным произведениям искусства» (Е.М. Верещагин, В.Г.Костомаров) русской литературы, что значительно способствует расширению «психолого-акмеологических возможностей формирования осознанных представлений о любви» (В.А.Смарышева) у иностранных учащихся на основе русской литературной традиции.

Одной из основных обучающих целей при использовании предлагаемого текста, наряду с формированием у иностранных учащихся социокультурной компетенции и навыков «письменного творчества» (Е.В.Бузальская) на русском языке, является совершенствование коммуникативно-речевых навыков. В связи с этим следует отметить, что, пожалуй, ни в какой другой сфере повседневной жизни индивидуальноязыковые предпочтения, речевое сознание и креативно-двигательное своеобразие человека не раскрывается с такой полнотой и яркостью, как в «сердечных» отношениях. Термин «речевое сознание» применён нами к литературной сфере на основе развития суждений Ф.-Г. Юнгера о соотношении языка и речи: в то время как язык, по мнению философа, является всеобщей человеческой потребностью, речь - это глубоко индивидуальная «доля» говорящего в языке, раскрывающая отношение личности к понятиям, характер человека и стиль его жизни. Поэтому «ни один говорящий не говорит так, как говорят другие» [14: 79-80]. Э.И. Котелевская, цитируя В.А. Салимовского, отмечает, что речевой жанр ухаживания содержит как прямые, так и косвенные способы выражения любовного переживания, и что «важнейшим содержательно-речевым средством непрямого выражения любовных переживаний выступают образные смыслы, воспринимаемые адресатом на основе его эмоционального опыта и позволяющие постичь духовный мир адресата» [7].

Речевой аспект темы любви и поиска того заветного, единственного слова для любимой (любимого) чрезвычайно характерен для русской литературы ещё с момента создания А.С. Пушкиным романа в стихах «Евгений Онегин», где Татьяна Ларина, влюбившись в Онегина, первая пишет ему письмо, мучительно подыскивая слова, которые бы напрямую шли от её сердца к его сердцу. Герой повести И.А. Бунина «Митина любовь» (1924), как и пушкинская Татьяна, пытается разобраться в природе своего чувства. Автор, используя несобственно-прямую речь, говорит о том, что Митя не мог отнести свою любовь ни к плотской, ни к бесплотной сфере, - она не была похожа ни на то, ни на другое. Этот влюблённый юноша - не поэт, но по своей внутренней природе человек одухотворённый и стремящийся к гармонии. Он живёт сложной эмоциональной жизнью, ему свойственно обострённое восприятие красоты и тайны окружающей природы, растительно-животного и вещественного мира. Всё вокруг наполнено для Мити не только его физическим влечением к Кате, но и ощущением возможности навеки, душевнодуховными узами соединиться с любимой: «Утреннее солнце блистало её (Катиной. - О.П.) молодостью, свежесть сада была её свежестью, всё то весёлое, игривое, что было в трезвоне колоколов, тоже играло красотой, изяществом её образа, дедовские обои требовали, чтобы она разделила с Митей всю ту родную деревенскую старину, ту жизнь, которой жили и умирали здесь, в этой усадьбе, его отцы и деды» [3: 362]. В отличие от мнения таких авторитетных исследователей произведения, как Фёдор Степун и Зинаида Гиппиус, мы считаем, что Митина страстность по отношению к Кате не сугубо физиологическая, а телесная - в том высоком понимании, о котором пишет в своей работе «Этика преображённого Эроса» (1931) Б.П. Вышеславцев, развивая христианскую антропологию апостола Павла: «Человек предполагает и содержит в себе все «дни 
творенья» и всю ту космическую иерархию бытия, которая в них развёртывается» [5: 285]. Стремление к гармонии с окружающим миром, центром которого становится для Мити эта и только эта, а никакая другая девушка, разрушается в нём лишь перед трагическим финалом. Автор так передаёт ощущение героем этого разрыва: Митя слышит шум дождя за окном, и сама мысль о соприкосновении тела с водной стихией кажется ему чудовищной. (В этом ощущении словно пребывает архетипическое переживание библейского Всемирного потопа.)

В наших новеллах мы стремились подчеркнуть не только то, насколько индивидуальнотворческим в каждом отдельном случае может быть речевой и «арт-пластический» (С.В. Дмитриев и его коллеги) диалог мужчины и женщины в зависимости от свойств их натуры и личностных качеств, но и в какой степени его обогащает искусство, культурно-эстетическая составляющая, идущая извне: литературная, музыкальнопоэтическая, театральная. Философ Пётр Успенский в работе «Искусство и любовь» (1911) писал, что любовь мужчины и женщины - это взаимное творчество, которое ведёт к совершенству мира; и что «в творчестве каждой эпохи можно найти след влияния женщинь данной эпохи. История культуры - «это история любви» [13: 225-226]. Подтверждение данной идеи опять находим в повести Бунина. Катя и Митя часто гуляют по Москве, по Тверскому бульвару, останавливаются у памятника Пушкину, и поэт становится для Мити частью того сказочного мира любви, которую он ждал с детства. Любовь и поэзия дали их отношениям мощный творческий заряд. Но, к сожалению, не все возлюбленные достойны «песен, ими вдохновенных» (А.С. Пушкин). Катя не поддержала эту энергию, и Митя погиб, не в силах далее оставаться в земном мире.

В сюжетах наших новелл, с одной стороны, любовь изображается как «антропологическая данность» (Э.М. Спирова), таинственная, неразгаданная стихия; с другой, присутствует мысль о том, что развитие каждой конкретной любовной коллизии зависит от реакции окружающих людей, от того, каким образом отношения двоих реализуются в жизни людского сообщества. Эта проблема была поставлена ещё в работе великого философа Николая Бердяева «Метафизика пола и любви» (1907), где он, в частности, отмечал, что мир ещё не готов для настоящей любви. Одно из самых глубоких литературно-художественных воплощений философской идеи Н.А. Бердяева снова находим в вышеупомянутой повести И.А. Бунина. Любовь Мити и Кати начинается как творческая, созидательная. А разрушается она не только из-за непомерно тщеславного желания Кати стать актрисой, её неверных онтологических жестов и речевого поведения в отношениях с Митей, но во многом из-за равнодушия матери героя, вмешательства в переживания Мити невежественного деревенского старосты, из-за ироничного отношения к первому чувству в обществе в целом.

Итак, сюжет каждой любовной новеллы нашего учебно-беллетристического текста помещён в определённое социокультурное пространство. А теперь постараемся дать краткий обзор и расскажем о художественной интерпретации вышеизложенных концептуальных положений в указанных новеллах цикла.

В новелле «Ах, ты, окно, откройся!» основным атрибутом «сердечного диалога» является музыкально-поэтический текст. Музыкальный язык, отмечает Н.А. Брылева, отличается особой сложностью, поскольку его определение и изучение нельзя ограничить «ни сферой техники музыкально-творческой деятельности, ни областью психологических закономерностей восприятия музыкального смысла. Совокупность ресурсов, обеспечивающих музыкальную коммуникацию как способ художественного отражения и выражения, представляя собой гибкую систему, тесно связанную с конкретным многомерным содержанием социокультурного процесса» [1]. Разделяя мнение музыковеда Г.Р. Тараевой, исследовательница пишет, что «способность музыки быть понятой, пережитой и осмысленной чётко указывает на необходимость рассмотрения её языка как своего рода «кодекса», установленного, точнее, выработанного социальной практикой художественной и общей культуры общества» [1]. Все эти особенности музыкального языка наглядно проявляются в вышеупомянутой новелле. В ней музыкально-поэтический текст чудесной неаполитанской песни Эдуардо ди Капуа и Винченцо Руссо «Maria, Mari» в первом русском стихотворном переводе М. Пугачева и И. Назаренко является тем пространственновременным центром, который, несмотря на некоторые одномоментные неурядицы, всё-таки становится для героев талисманом на долгую и счастливую семейную жизнь. А также, при всей сложности музыкального языка, оказывается единственно возможным способом коммуникации персонажей в одной из самых деликатных и затруднительных ситуаций общения: первого знакомства мужчины и женщины. Они чувствуют сильное взаимное притяжение и находятся в интенсивном поиске: как, каким индивидуальным способом донести это друг до друга? Место действия новеллы - московская квартира их общих знакомых, где собралось много гостей. Время действия - начало 1950-х годов. Согласитесь, что если принять во внимание социокультурный контекст означенного периода, то, в отличие, скажем, от XIX века, в арсенале персонажей этой новеллы очень мало предметных атрибутов выражения своего индивидуального отношения к представителю противоположного пола, - каким был, к примеру, для женщины позапрошлого века веер. Конечно, извечным атрибутом таких отношений, особенно на начальном этапе, являются цветы, которые мужчина дарит женщине. Герой не догадался купить их. Но даже если бы он 
пришёл в гости с букетом цветов, то, конечно, сразу преподнёс бы их хозяйке дома. Так что в обоих случаях это равно не являлось бы решением проблемы. Другим «креативным двигательным действием» (С.В. Дмитриев и другие) в ситуации первого ухаживания за женщиной могло бы стать приглашение на танец. Но ни он, ни она танцевать не умеют. Зато герой занимается в любительской оперной студии, и у него приятный баритон. Поэтому в означенной ситуации он выбрал самое лучшее индивидуальное решение - начал петь. Даже вопреки тому, что его внешний вид в данный момент совсем не соответствует имиджу певца и потенциального жениха: накануне герой играл с друзьями в волейбол, и ему случайно попали в ухо мячом. Поэтому у него перевязано правое ухо и, естественно, часть головы и лица. Но то, как герой поёт, находчиво заменив по ходу исполнения имя «Мари'» на «Ани'», - французская огласовка имени понравившейся ему девушки - «Анна», удачно вписав его в русский поэтический текст, при этом сохранив музыкальную интонацию оригинала; и то, как героиня, - которая в силу своей невероятной скромности никогда не решилась бы стать инициатором в передаче коммуникативного сигнала симпатии к мужчине, - слушает его пение, невзирая ни на что становится идеальным способом донести друг до друга колоссальный взаимный интерес. И не только. Этот эпизод - в виде воспоминания, время от времени озвучиваемого участниками события, и как ритуал праздничного застолья, - навсегда входит в традицию созданной героями счастливой семьи, а также в естественный сценарий продолжения дружеских отношений с теми людьми, которые их познакомили. Добавим ещё один социокультурный штрих: на 1950-е годы приходится пик популярности неаполитанских песен в нашей стране.
Понятие любви как диалога двух сердец неразрывно связано с христианской традицией, что также нашло отражение в наших новеллах.

Новелла «Два снегопада» повествует об экскурсионной поездке в белорусские города Минск и Полоцк, во время которой центральная героиня цикла Алина познакомилась со своим будущим мужем Андреем Болтрушевичем, белорусом по национальности. Интимнолирическая наррация тесно переплетена здесь с наррацией религиозно-исторической, поскольку во время ночной прогулки по заснеженному древнему городу будущий спутник жизни поведал Алине удивительную историю о «трёх Софиях», то есть трёх Софийских соборах - в Киеве, Новгороде и Полоцке - как основе древнерусского духовного и государственного пространства. Для рассказа Андрея Болтрушевича мы использовали информацию из выступления по Радио России современного учёного-историка Юрия Борисёнка [8]. Музыкально-поэтический интертекст: стихотворение Бориса Пастернака «Снег идёт» в исполнении знаменитого барда Сергея Никитина. Литературно-драматические, театральные и кинематографические аллюзии: пьеса Эдварда Радзинского «Приятная женщина с цветком и окнами на север», спектакль «Аэлита» (1983) по этой пьесе, поставленный Евгением Лазаревым в Московском театре эстрады; в главной роли Народная артистка СССР Татьяна Доронина; фильм «Аэлита, не приставай к мужчинам» (1988) по мотивам пьесы, в главной роли - Народная артистка РСФСР Наталья Гундарева. Режиссёр Георгий Натансон, музыка Микаэла Таривердиева. Во всех перечисленных художественных интерпретациях пьесы присутствует авторская мысль литературного первоисточника, тесно связанная с сюжетом нашей новеллы: любовь начинается не только с первого взгляда, но и с первого рассказа.

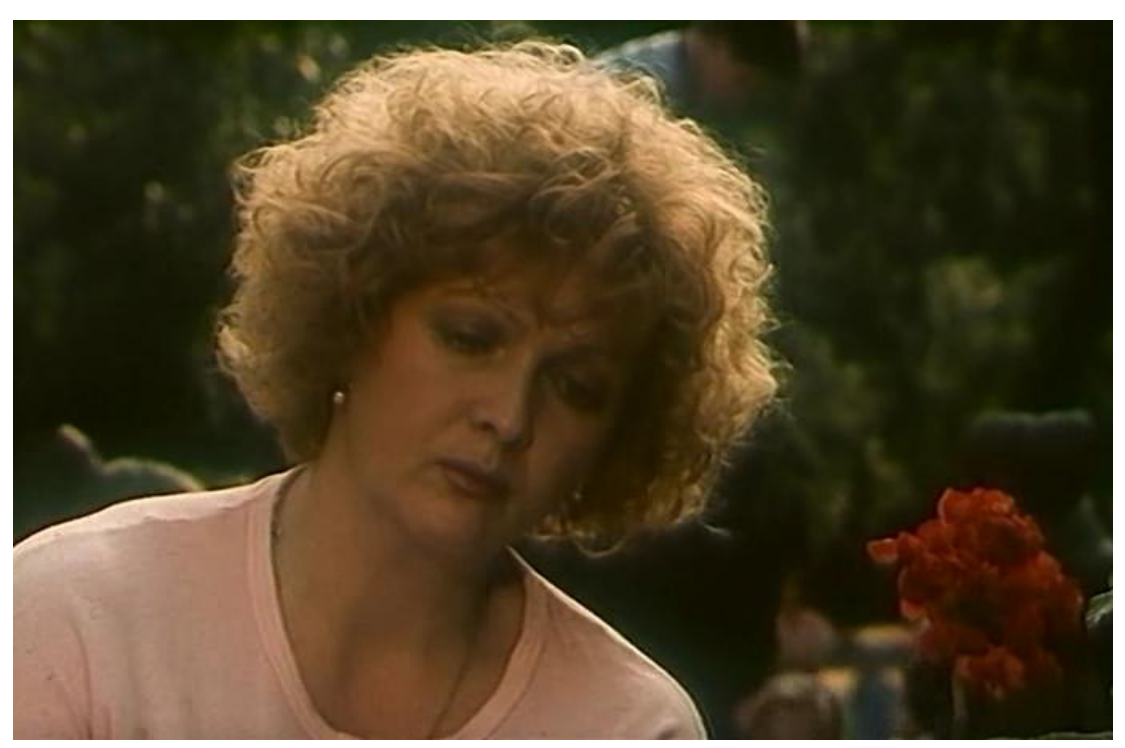

Наталья Гундарева, любимица миллионов, в фильме «Аэлита, не приставай к мужчинам». 


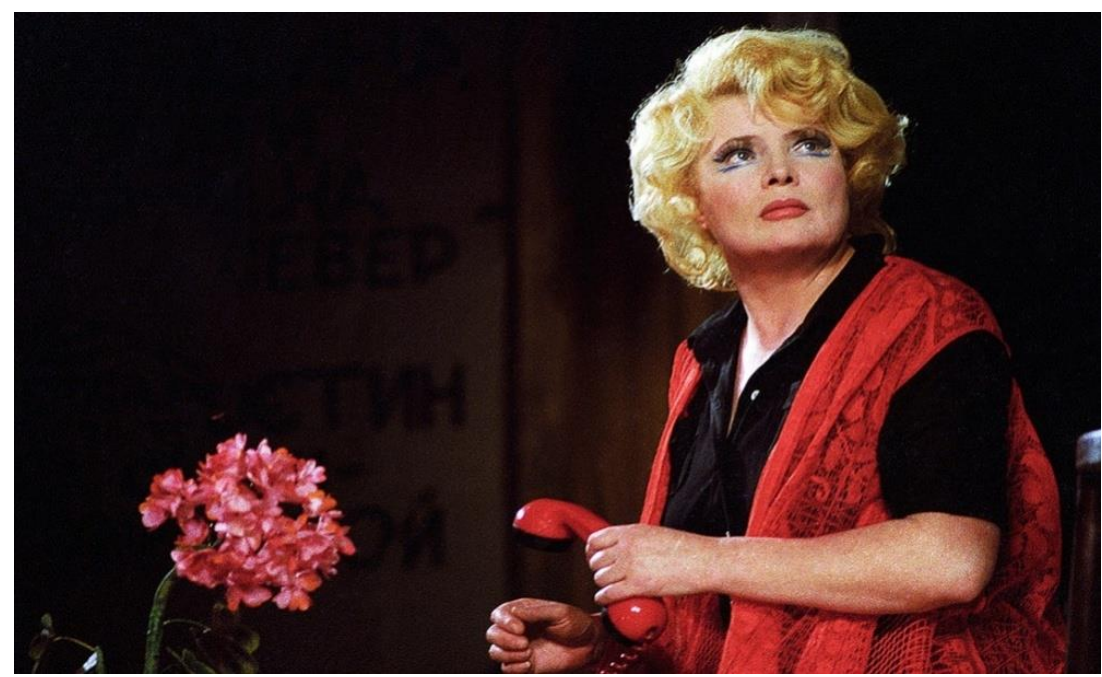

Татьяна Доронина, которую называют «русской Мэрилин Монро», в спектакле «Аэлита».

Сердечный диалог в новелле «Первая любовь светла и грустна...» основан на речевом взаимодействии Алины - персонажа-носителя языка - с Алексом - персонажем-представителем иноязычной - североамериканской - культуры. Несмотря на ментально-языковой барьер, тематика их общения разнообразная и чрезвычайно искренняя. События развиваются в Москве конца 1980-х годов. В те годы, когда значение Русской Православной Церкви в обществе только начинало восстанавливаться, Алекс часто рассказывал Алине о Христе - по-своему и немного наивно. Этим моментом подчёркивается неподвластность любви географическим и идеологическим границам, утверждается её понимание как главной духовной жизненной силы, о чём писал ещё И.С. Тургенев в своём цикле «Senilia Стихотворения в прозе»: «Любовь, думал я, сильнее смерти и страха смерти. Только ею, только любовью держится и движется жизнь» [11]. Литературной аллюзией, связанной с любовной тематикой, становится упоминание о романе М.А. Булгакова «Мастер и Маргарита». Её дополняет реальная история любви всенародно признанного поэта, актёра, барда Владимира Высоцкого и знаменитой французской актрисы русского происхождения Марины Влади. Музыкально-поэтический интертекст: «Песня о первой любви» (композитор - Андрей Петров, поэт - Леонид Куклин).

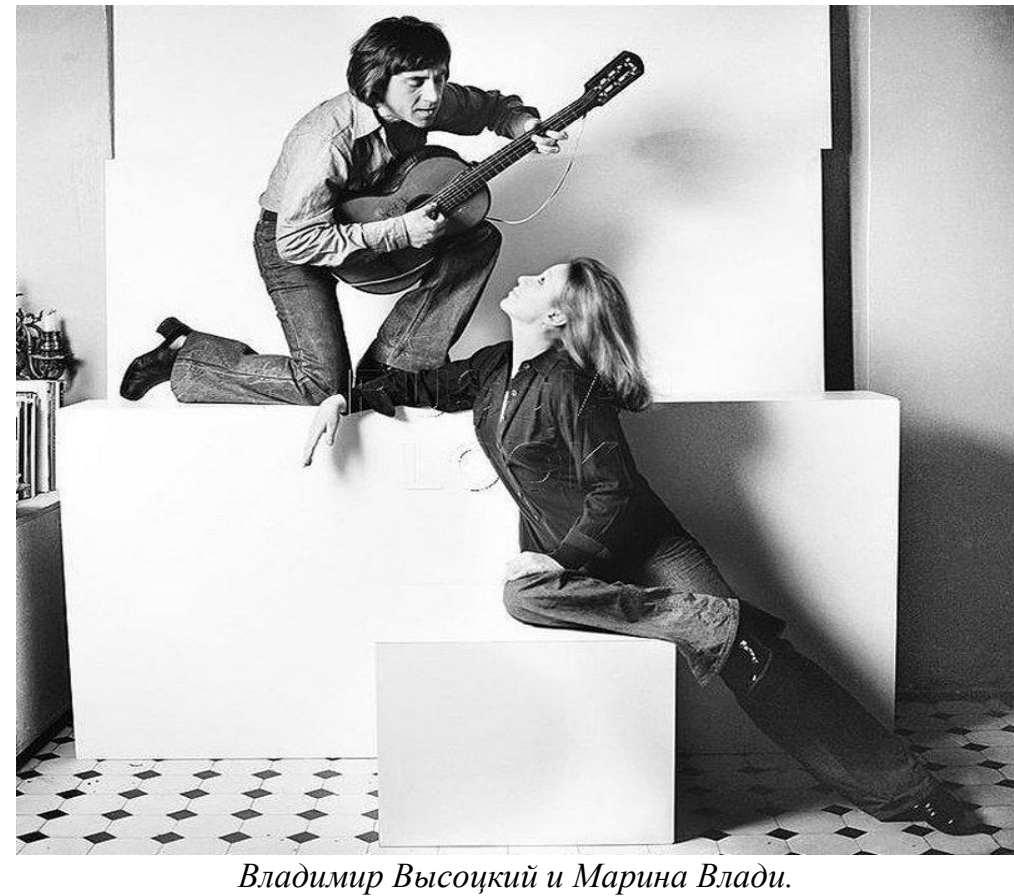

Во всех любовных новеллах нашего цикла доминирующим креативно-

телесным атрибутом любовного влечения мужчины и женщины является взаимодействие их взглядов - не как флирт или кокетство, а как отражение искреннего чувства, идущего из глубины сердца. И.В. Брылина в статье «Философия русского эроса как социокультурный феномен», ссылаясь на древнерусского автора, Киевского митрополита Илариона и его версию 
Крещения Руси, а также на мысли из монографии Г.Я. Стрельцовой «Паскаль и европейская культура», пишет: «Русская культура с древнейших времен восприняла христианское учение о любви и сердце. В древнерусском памятнике XI века «Слово о законе и благодати» Киевский митрополит Иларион основной причиной крещения князя Владимира приводит тот факт, что «взглянуло на него око благого Бога, и воссиял разум в сердце его» <...> «Разум, воссиявший в сердце», и «зрячие очи сердца» - это не просто образные метафоры древности, а следование традиции христианского вероучения о сердце и любви. Оно в русской религиозной культуре просуществовало вплоть до начала XX века. Многие философы, писатели и поэты в своем творчестве обращались к глубинному символу сердца. Русские создали уникальную «метафизику сердца», дополнившую западноевропейскую «метафизику разума» <...>» [2].

В чётвертой новелле - «Вид из окна, или Московская мелодия», посвящённой уже любовнобрачным отношениям, рассказывается о том, как Алина с мужем Андреем любят смотреть на окружающий мир из окна своей небольшой квартиры. Пространство оконного проёма, жизнь деревьев и птиц за ним, которая сопоставима с людскими судьбами, оказываются для Алины эмоционально-визуальным центром, где сходятся в одно целое особенно значимые по смыслу моменты детства, молодости, влюблённости, супружества. И Андрей ощущает в такие минуты то же самое, что и она. Ведь в их сердцах уже много лет звучит единая музыка любви, а глаза давно видят мир в одинаковом измерении. Новелла содержит явные и скрытые литературные, театральные, кинематографические и песенные аллюзии: повесть И.А. Бунина «Митина любовь» (1924), спектакль «Варшавская мелодия», поставленный Рубеном Симоновым в Театре имени Евгения Вахтангова по любовной драме Леонида Зорина, первоначальное название которой - «Варшавянка»; фильмспектакль «Варшавская мелодия», снятый Центральным телевидением на основе одноимённого спектакля (1969); современный спектакль «Варшавская мелодия» в Театре на Малой Бронной; рассказ Валентина Распутина «Василий и Василиса» и одноимённый фильмдрама (1981) режиссёра Ирины Поплавской; песня Александры Пахмутовой на стихи Николая Добронравова «Мелодия» в исполнении Муслима Магомаева. Эпиграфом к новелле стали музыкально-поэтические строки Олега Митяева «Есть начало и конец у любой истории. // Нас несёт в фантазии завтрашнего дня. // Снятся мне попрежнему светлые мелодии, // Только не встречается лучше, чем твоя» («Самая любимая песня») []. Образный ряд данного песенного текста необычайно эстетичен и близок нашей новелле: птицы, деревья, осенние плывущие листья (т.е. листы,

Письмена судьбы. - О.П.) « с запахом будущей пурги», которые «читает»

лирический герой своей любимой женщине; и те же письмена - на

«прожилках» её «лиственной руки». Осенняя мелодия любви печальна, но нет

ничего светлее и прекраснее, чем она.

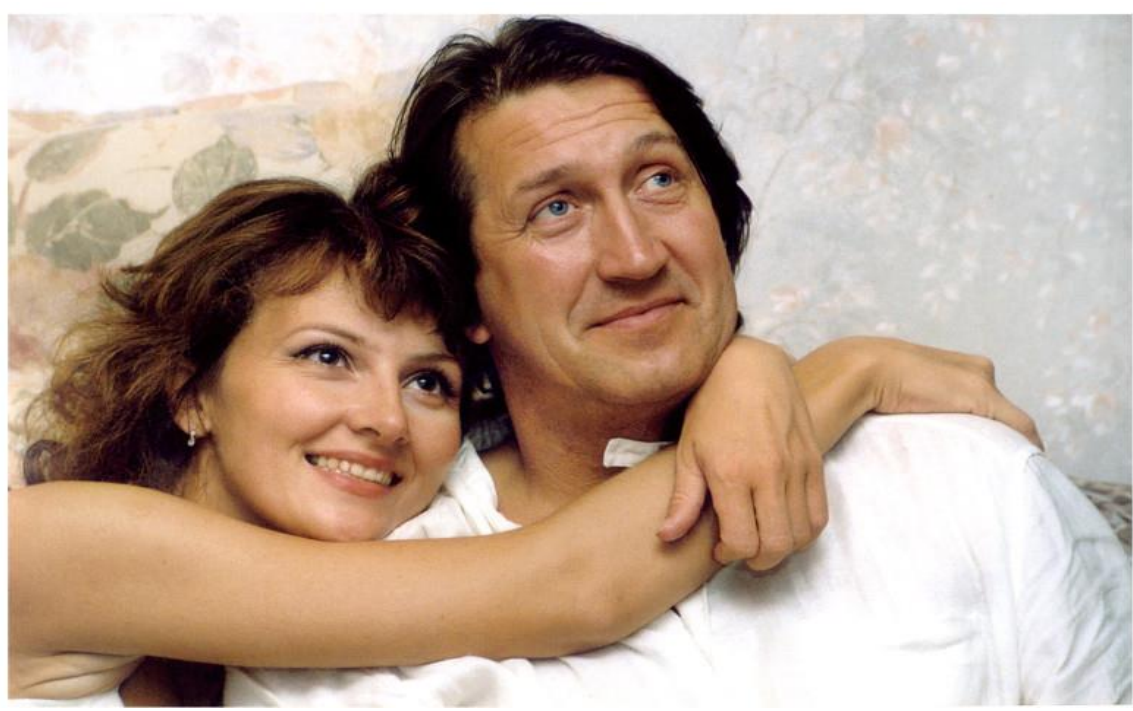

Член Союза писателей России, Народный артист Российской Федерации

Олег Митяев с супругой Мариной Есипенко - Народной артисткой России, ведущей актрисой

Государственного академического театра имени Евгения Вахтангова. 


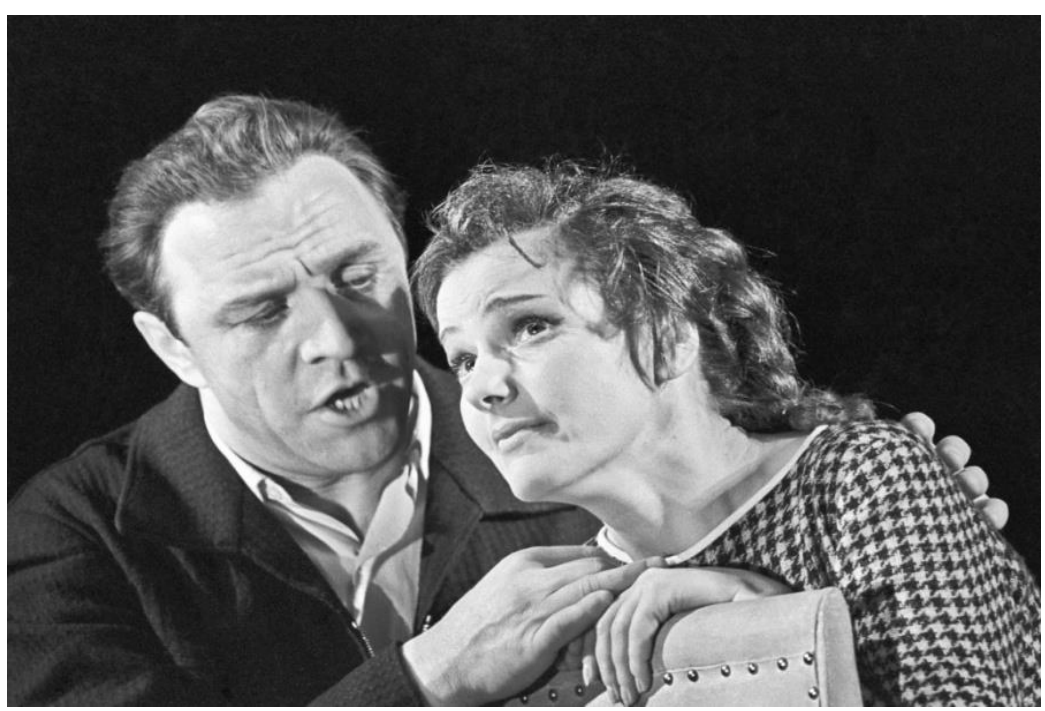

Сиена из спектакля «Варшавская мелодия». Гелена (Геля) - Народная артистка СССР Юлия Борисова, Виктор (Витек)- Народный артист СССР Михаил Ульянов (1927 - 2007)

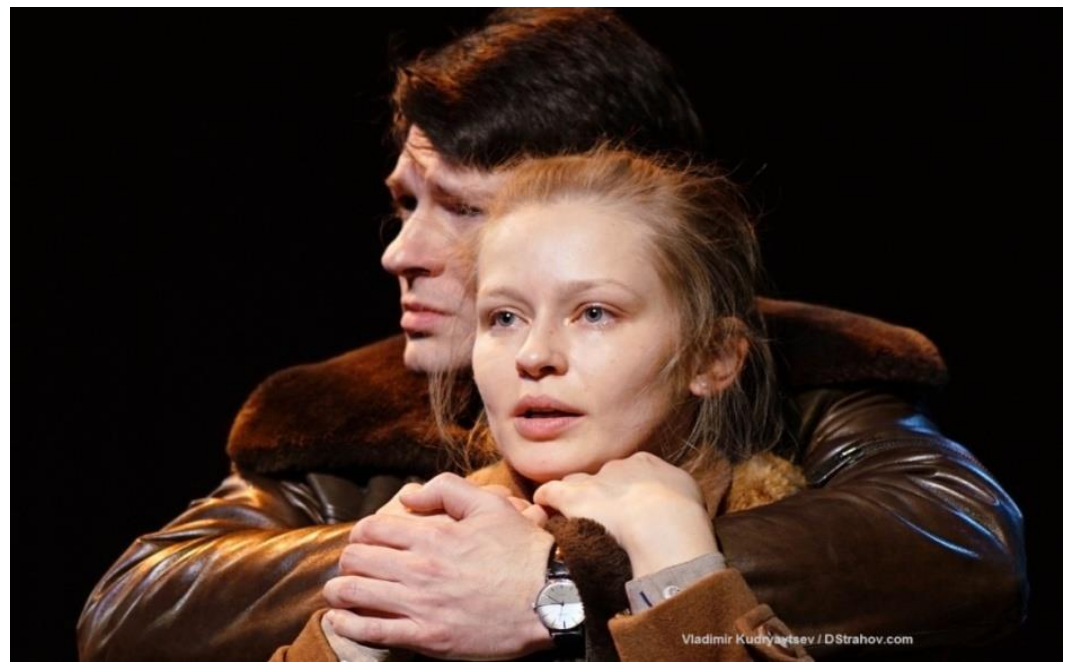

Современньй спектакль «Варшавская мелодия» в Театре на Малой Бронной. Гелена (Геля) Заслуженная артистка Российской Федерации Юлия Пересильд, Виктор (Витек)-лауреат Премии Правительства Российской Федераџии Даниил Страхов. Режиссёр-постановщикЗаслуженный деятель искусств Российской Федерации Сергей Голомазов.

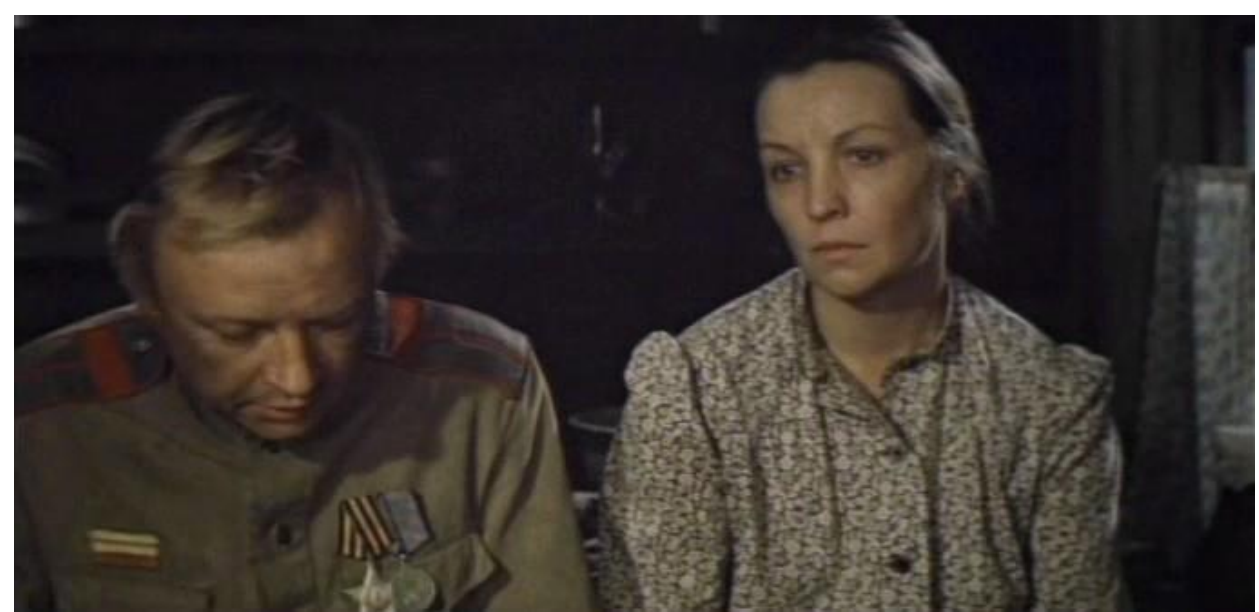

Кадр из фильма «Василий и Василиса». Василиса - лауреат Государственной премии СССР и ныне Народная артистка Российской Федерации Ольга Остроумова; Василий - Народный артист РСФСР Михаил Кононов (1940 - 2007). 


\section{Иван Бунин \\ и Варвара Пащенко}

Юный Иван Бунин, будущий лауреат Нобелевской премии в области литературы, и его первая любовь Варвара Пащенко.

В заключение отметим, что в одном из новейших отечественных пособий по развитию речи для продвинутого этапа обучения РКИ выделены следующие разговорные темы и составлены соответствующие учебные тексты к ним: «Тема 1. Знакомство. Расскажите о себе $<\ldots .>$ Тема 2. Клуб по интересам <..> Тема 3. Национальная кухня <..> Тема 4. Знаменитые люди. Принцесса Диана $<\ldots>$ Джон Леннон $<\ldots>$ Наполеон I Бонапарт <..> Вольфганг Амадей

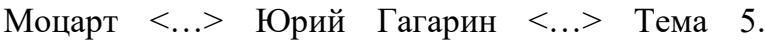
Удивительное рядом <..>» [6: 4-48]. Нетрудно заметить, что тема любви здесь отсутствует. Однако кому как не нам - преподавателям РКИ особенно сподручно, в силу межкультурной специфики нашего профессионального поприща, внести посильный вклад в активизацию такого мощного ресурса для занятий по практике речи методического, эстетического, этического. Автор данной статьи предлагает использовать для этого новеллы о любви, представляющие собой учебнобеллетристический текст преподавателя, который можно считать одной из форм интерактивного подхода и применения «художественнопедагогических технологий» (Л.М. Масол и другие) в обучении русскому языку как иностранному.

Приложение. «Первая любовь светла и грустна...»

(Новелла о первом чувстве, которое кто-то назовёт банальным, а кто-то - уникальным.)

Первая любовь светла и грустна.

Что там ждёт впереди?

Из популярной

эстрадной песни

1970-х годов.
Трудно найти в России человека, который не знал бы следующей фразы: «Онегина» можно назвать энциклопедией русской жизни и в высшей степени народным произведением». Эта фраза о романе в стихах А.С. Пушкина «Евгений Онегин» принадлежит В.Г. Белинскому - выдающемуся литературному критику 19 века, младшему современнику Александра Сергеевича.

Но далеко не все знают, что в русской литературе существует и другая универсальная книга - «энциклопедия любви», созданная Иваном Алексеевичем Буниным. Такое определение, и совершенно заслуженно, дал его циклу новелл «Тёмные аллеи» исследователь Юрий Мальцев. А у самого Бунина есть где-то мысль о том, что сюжет о первой любви может показаться банальным только тому человеку, который не знает этого чувства, не испытал его на собственном опыте. Мы думаем точно также. А потому включили в наш повествовательный цикл новеллу о первой любви Алины.

Москва. Конец февраля и конец 1980-х годов. Ещё зима, но в морозном воздухе и в тумане метели уже появилось что-то неуловимо-весеннее. Может быть, это душевные флюиды, исходящие от миллионов горожан? Флюиды ожидания счастья. Человек и природа торопятся навстречу друг другу...

Воскресный вечер. Алина Земскова, студентка педагогического института, и её подруга Наташа Кузнецова сидят в уютном кафе в центре

Москвы и лакомятся взбитыми сливками. Из окна кафе виден семиэтажный дом дореволюционной постройки на улице Мархлевского (сейчас это Милютинский переулок). Здесь, в одной коммунальной квартире, 
прошло их раннее детство. Здесь они начали осваивать мир по сантиметрам пространства и по мгновениям времени, произнесли первые слова и сделали первые шаги. Здесь впервые стали отличать самые близкие лица от тех, что подальше. Вот он, этот дом, совсем рядом, такой родной и привычный, но уже не их...

Наташина мечта - стать кинорежиссёром. Девушка уже три раза пыталась поступить во ВГИК - Всесоюзный государственный институт кинематографии имени С.А. Герасимова (сейчас первая буква аббревиатуры расшифровывается как «Всероссийский»). Конкурс туда, особенно на актёрский и режиссёрский факультеты, громадный, до тысячи человек на место, а то и больше. Сегодня, как и в других вузах страны, там можно учиться не только на бюджетной, но и на платной основе. А в то время такой альтернативы у абитуриентов не было.
Наташе на редкость подходит профессия, связанная с актёрским искусством, даже по внешнему типажу. Очень высокая, с роскошной пепельной косой и выразительными серо-голубыми глазами, она сильно напоминает обликом хара'ктерную актрису Татьяну Васильеву. (Сейчас у неё звание Народной артистки Российской Федерации. Рост актрисы - 176 сантиметров.) Да и темперамента Наташе так же, как знаменитой артистке, не занимать. И фантастической целеустремлённости, кстати говоря, тоже. А потому, доев взбитые сливки, она сразу же заторопилась домой, опять к своим книгам, - по актёрскому и режиссёрскому мастерству, к работам своего кумира - великого К.С. Станиславского. Девушки обнялись, расцеловались и разбежались в разные стороны - до следующей встречи.

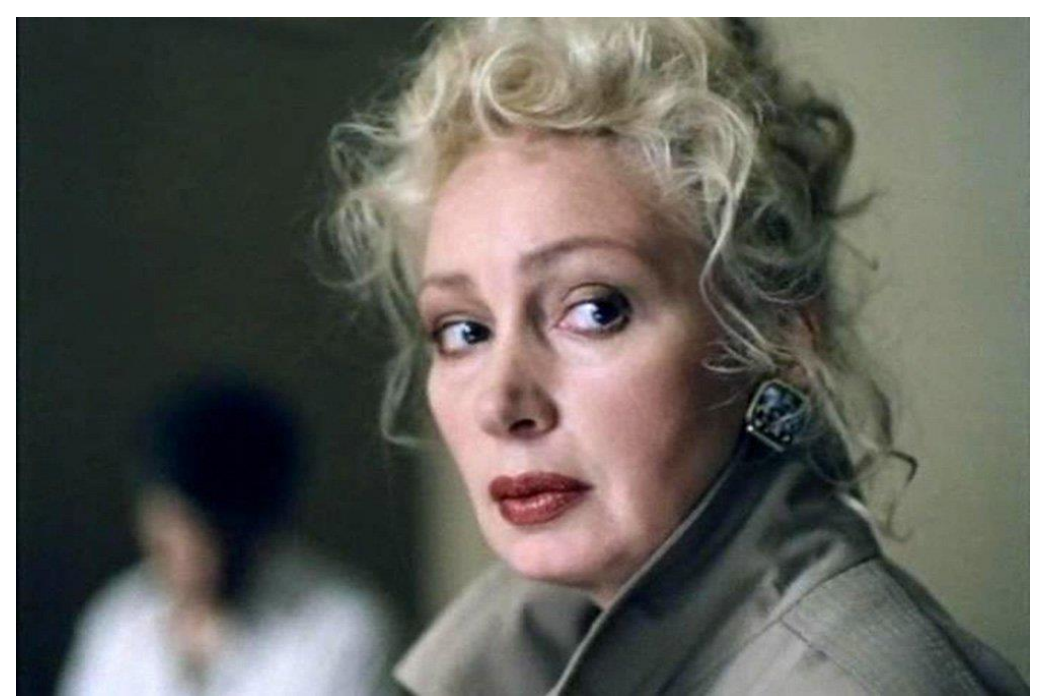

Народная артистка Российской Федераџии Татьяна Васильева.

Имеет государственную награду: орден Почёта «за большие заслуги в развитии отечественной культуры и искусства, многолетнюю плодотворную деятельность» [4]. На её счету - более ста ролей в кино и десятки театральных ролей. Но, пожалуй, есть среди них три, благодаря которым Татьяна Григорьевна стала всенародно любимой актрисой. Это, во-первых, роль Доротеи в музыкальной кинокомедии «Дуэнья» по одноимённой пьесе Ричарда Б. Шеридана. Автор сценария и режиссёрпостановщик - Михаил Григорьев, композитор Народный артист СССР Т. Н. Хренников. Вовторых, Марья Антоновна (дочка городничего) в спектакле «Ревизор» по одноимённой комедии Н.В. Гоголя в Московском театре Сатиры. Режиссёрпостановщик - Народный артист СССР Валентин Плучек. В-третьих, роль Сусанны - психолога, изучающего проблемы брачных союзов, - в лирической кинокомедии «Самая обаятельная и привлекательная». Авторы сценария: Геральд Бежанов и Анатолий Эйрамджан. Режиссёр Геральд Бежанов. Сусанна со всей искренностью и душевной энергией стремится научным способом выдать замуж школьную подругу. При этом она даже не подозревает, что ей само'й давно изменяет муж. 


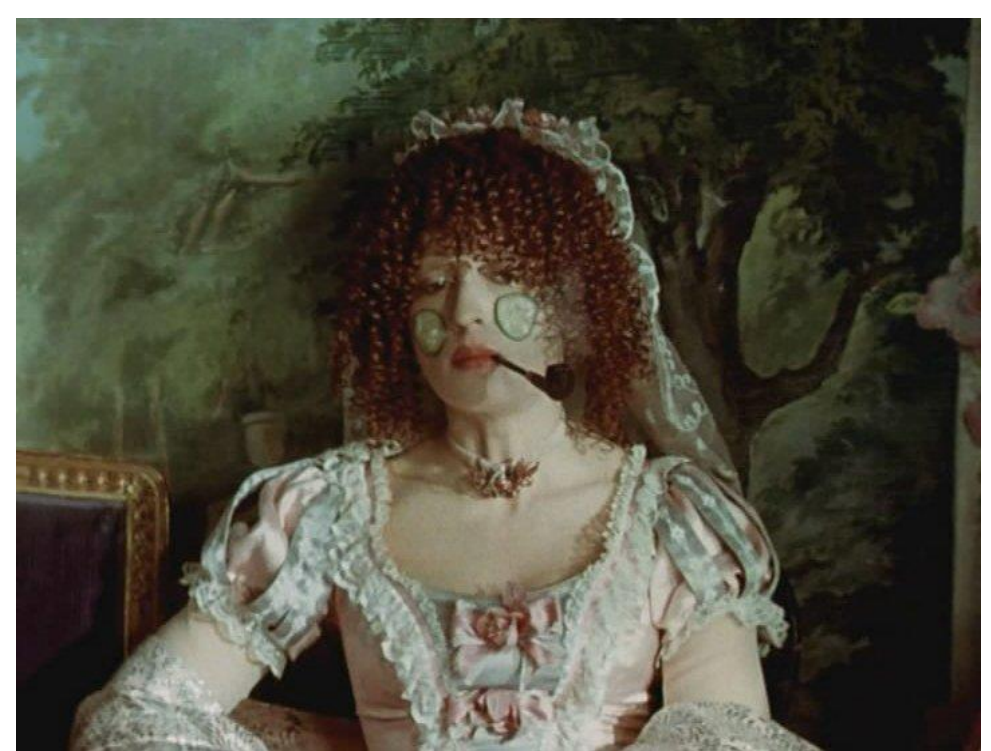

Татьяна Васильева в фильме «Дуэнья».

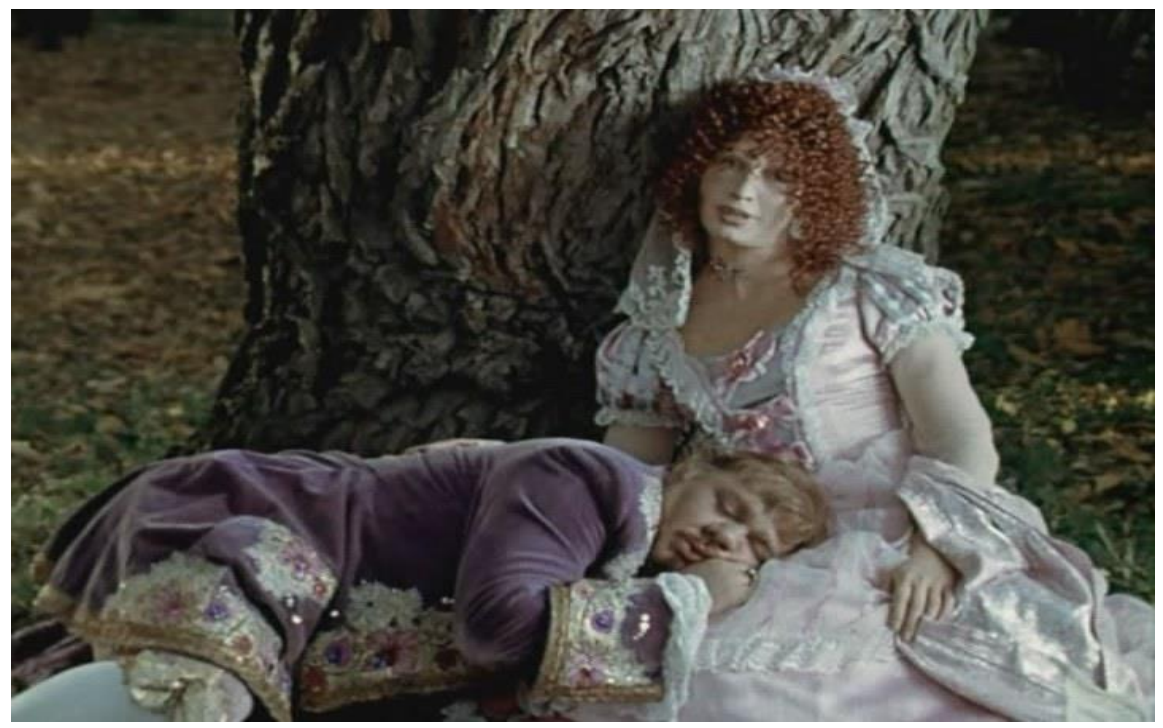

Татьяна Васильева и Евгений Леонов в фильме «Дуэнья».

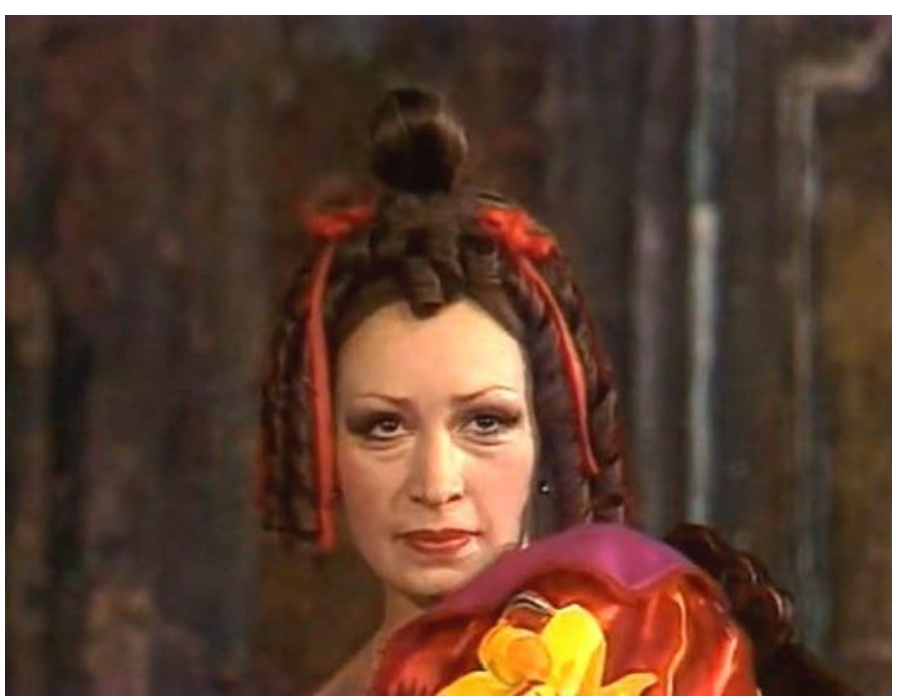

Татьяна Васильева в спектакле «Ревизор». 


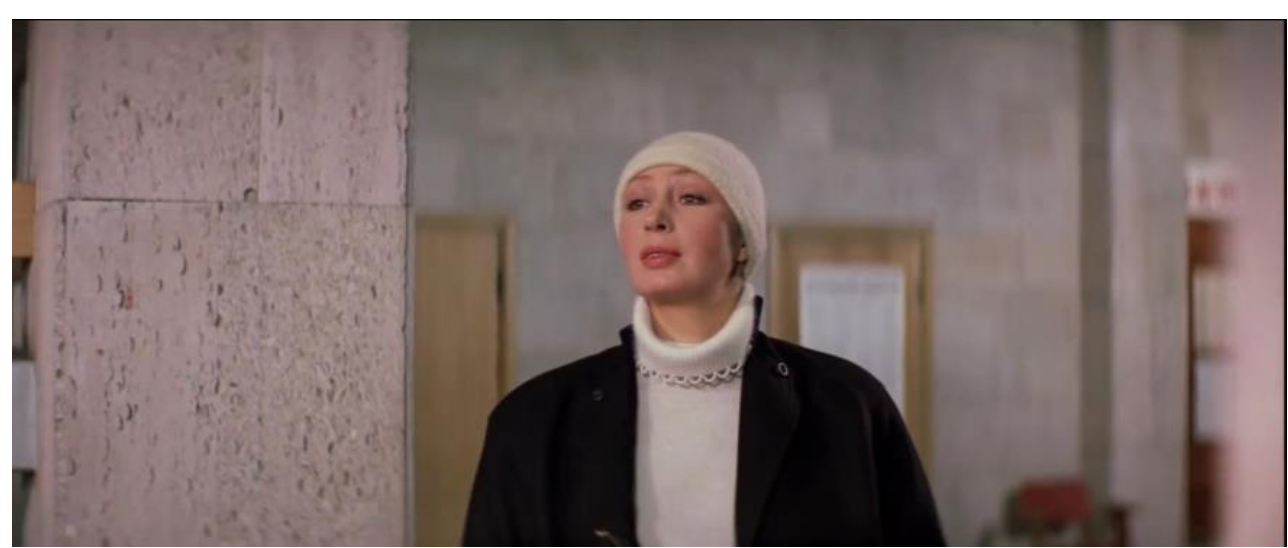

Татьяна Васильева в фильме «Самая обаятельная и привлекательная».

Оставшись одна, Алина решила прогуляться по центру и пошла на Театральную площадь. Было ещё только начало седьмого. Вечерняя многолюдная Москва манила воображение силуэтами шуб, дублёнок, пальто и курток; обрывками фраз, внезапно мелькнувшим в толпе лицом; спокойным, уютным светом жилых окон, нарядно-зазывными огнями кинотеатров, магазинов и ресторанов. Девушка любила иногда вот так побыть среди людей, одновременно оставаясь в своей скорлупе. А среди мимолётных впечатлений огромного города всегда находилось как минимум одно особенно трогательное, наполнявшее душу жизненной энергией. Сегодня это был неуклюжий малыш, в своей цигейковой шубке похожий на медвежонка. Мама везла его на санках, а он вдруг выпал из них. Мама испугалась, тут же присела около него. И тогда он снял варежки, обхватил ручонками её миловидное лицо и кротко прошептал: «Мамочка, я тебя так люблю!»

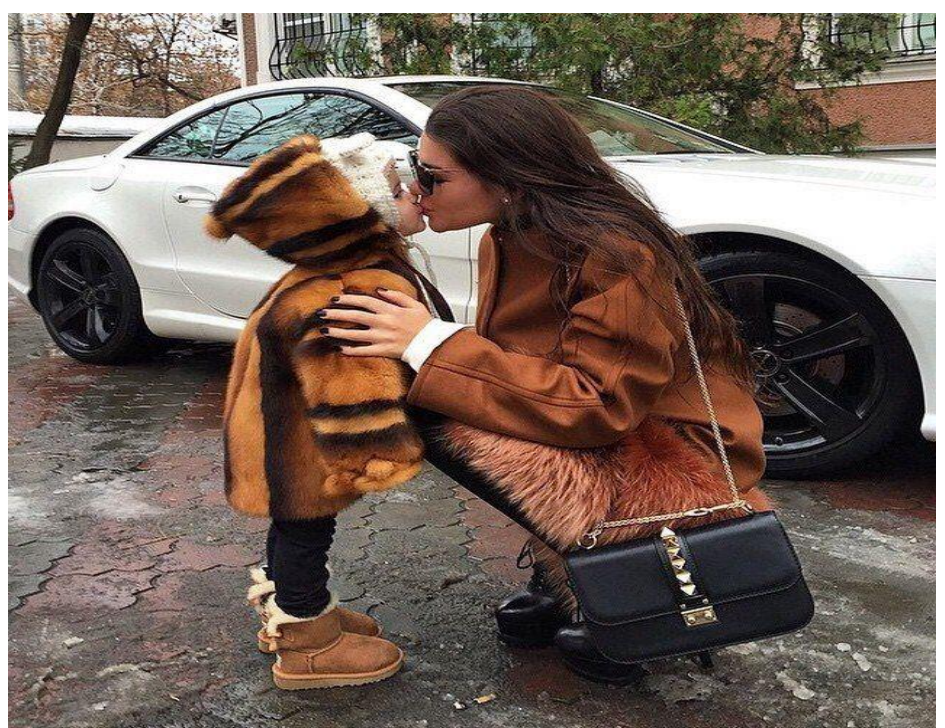

«Мамочка, я тебя люблю!

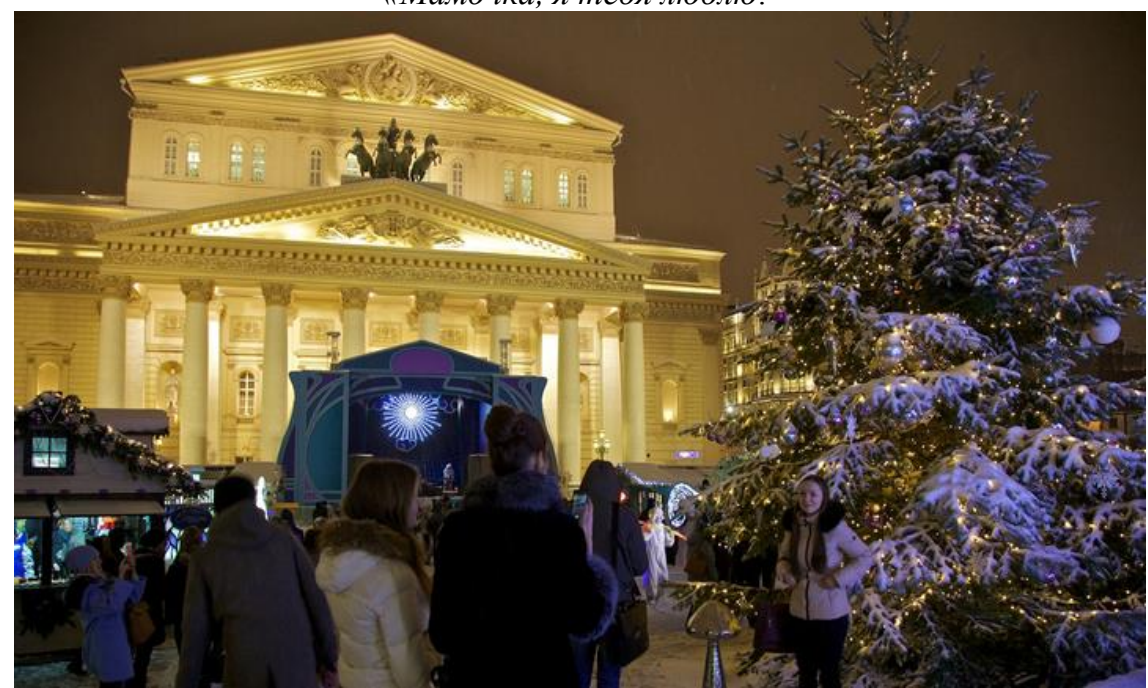

У Больщого театра в новогодние праздники. Театральная площадь, дом 1. 
Очутившись на Театральной площади, Алина первым делом подошла к афише Большого посмотреть, что сегодня дают. Это был балет П.И. Чайковского «Щелкунчик» с Екатериной Максимовой и Владимиром Васильевым. «Вот счастливчики!» - подумала она о тех, кто подходил к театру, доставая билеты из театральных сумочек (женщины) или внутренних карманов пальто (мужчины).

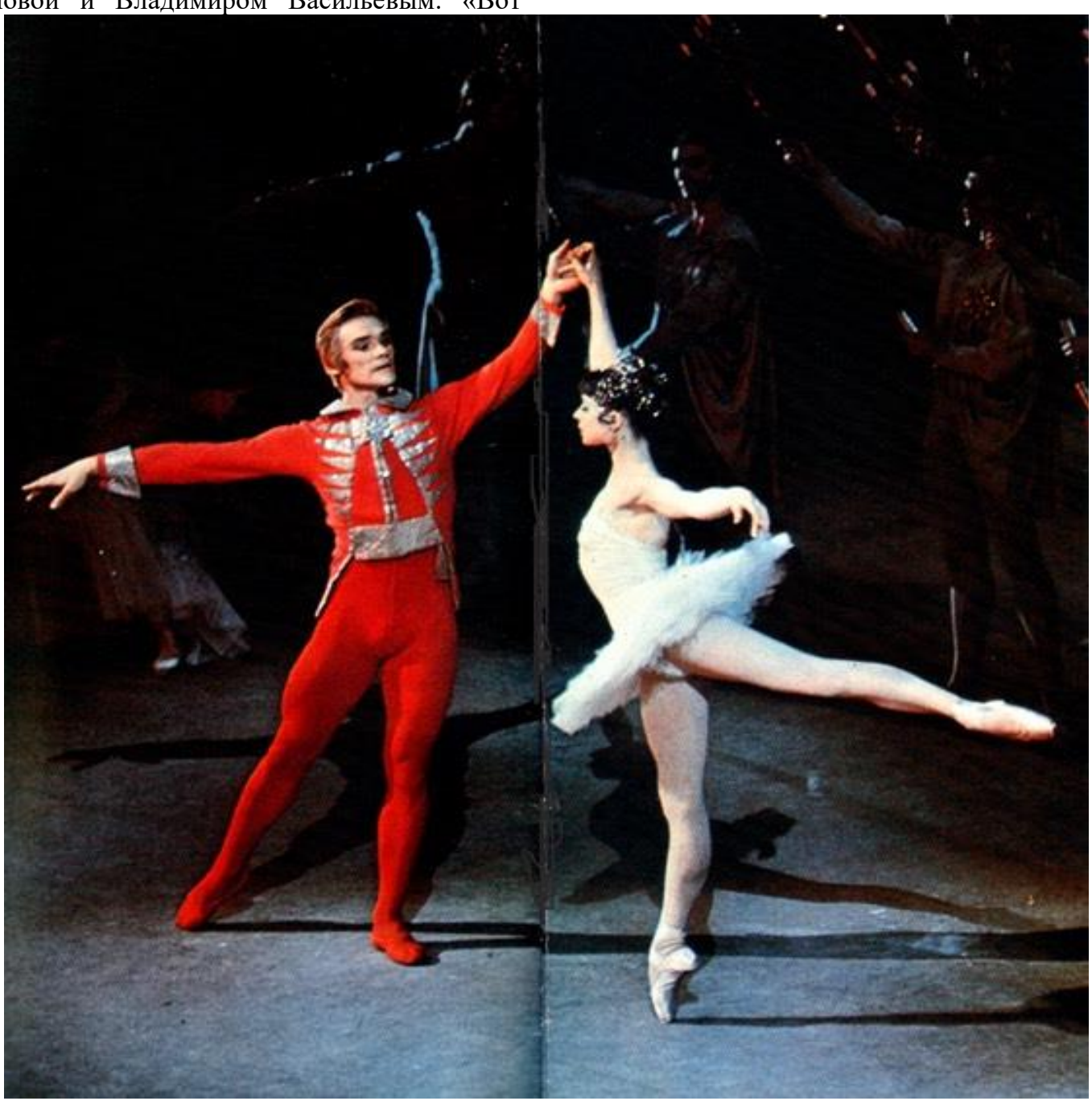

Народные артисты СССР Екатерина Максимова и Владимир Васильев в балете П.И. Чайковского «Щелкунчик» на сиене Больиого театра в Москве.

В Малом давали комедию А.Н. Островского «На всякого мудреца довольно простоты». Её названием, как и многих других комедий драматурга, стала русская пословица. Алина обожала его пьесы. В них всегда захватывающая сюжетная интрига, национальный колорит характеров, потрясающе выразительный язык и, как у Бунина, русская «энциклопедия любви», только в драматургии. «Может, попробовать какнибудь достать билет, хотя бы на галёрку?» мелькнула мысль. Алина стала оглядываться по сторонам... Неисповедимы пути Господни! В нескольких шагах от неё, около памятника А.Н. Островскому, стоял известный артист Игорь Васильев! «Разве он сейчас в Малом, а не в Художественном? - подумала она в замешательстве. - И одет как-то уж чересчур демократично для такой знаменитости - голубые джинсы, тёмно-синяя куртка и спортивная шапка серого цвета. Может, он так прячется от поклонниц? Всё равно, надо бы подойти и попросить автограф». Алина открыла сумочку, достала миниатюрную телефонную книжечку с золотистой бабочкой на обложке и медленным, неуверенным шагом направилась к любимому артисту... Неожиданно он развернулся и быстрым шагом сам подошёл к ней! «Будьте добры, пожалуйста, мне надо этот театр», - сказал он с сильным акцентом, показывая ей билет в МXТ имени Чехова (Московский художественный театр имени А.П. Чехова). Алина сразу поняла, что это не розыгрыш. Акцент ещё можно подделать, но органика не совсем правильного построения фразы говорила сама за себя. «Вот так номер! ошарашенно подумала девушка. - Игорь Васильевто, оказывается, иностранец! Надо же, какое сходство! Одно лицо, да и только!» Алина кое-как справилась с шоком и стала объяснять: «Это совсем недалеко. Сейчас пойдёте по Пушкинской улице [12], всё время прямо. Пройдёте Театр оперетты, затем - Дом педагогической книги и выйдете в Камергерский переулок. Там находится театр, 
который Вам нужен». - «Большое спасибо», ответил молодой мужчина и продолжал стоять, переминаясь с ноги на ногу. Алине показалось, что он хочет сказать ей что-то ещё. И она не ошиблась. - «Моё имя Алекс. Я американец. А как Ваше имя?» - спросил он, калькируя английскую фразу. «Алина», - ответила она. - «Мне очень приятно. У Вас красивое имя. Но я не так часто слышал его здесь», - поделился мужчина своим страноведческим опытом. - «Да, для русских имён оно достаточно редкое. Но сейчас это имя стало у нас более популярным», - добавила она. - «Ага!
Понятно!» - сказал он приподнятым тоном, радуясь новой информации. И вдруг предложил: «Алина, Вы не хотели бы просто пойти в театр, чтобы смотреть этот вещь? Сейчас мы идём туда, и я даю Вам свой билет». Подскажите, друзья: какими очень разговорными словами выражается в современном русском языке крайнее изумление? «Звезда в шоке!» - кажется, так? Да-да, именно так. Это выражение пришло в народ от Сергея Зверева легендарного топ-стилиста, мастера парикмахерского искусства и эпата'жа. Алина не знала, что ответить. Пауза

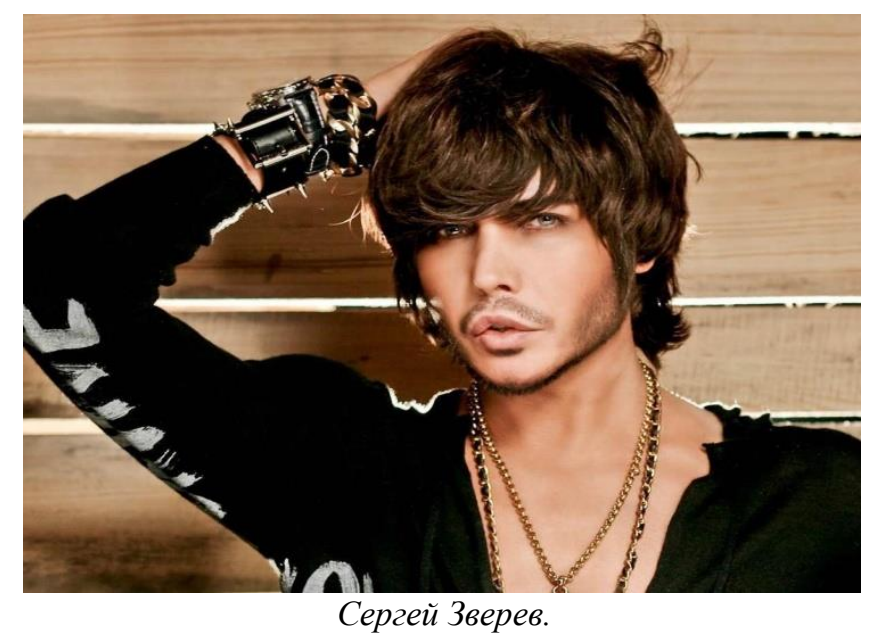

затянулась. Их карие глаза встретились... А вслед за этим наступило мгновение, которое знакомо многим и которое все называют поразному: «искра пробежала по всему телу», «сердце забилось в груди», «любовь с первого взгляда», «ощущение крыльев за спиной», «И в мыслях молвила: вот он!» - последнее выражение уже из Пушкина, из знаменитого «Письма Татьяны к Онегину». И Алина, сама себя не узнавая, согласилась на предложение Алекса.

Спектакль был тот же, что и в Малом театре, Островский, «На всякого мудреца довольно простоты». Обаяние Алекса, его трогательный акцент, смущение Алины - всё это благотворно подействовало на кассиршу театра. И она дала им контрамарку. Это бесплатная возможность сесть в зале на любое свободное место.

Они сидели в партере - правда, не четвёртом ряду, как было указано на билете Алекса, а в десятом. И не в центре, а с краю. Там случайно оказалось два свободных места сразу. В партере этого театра восемнадцать рядов. Так что с местами им ещё очень повезло, можно сказать. Глумова играл Игорь Васильев - как всегда, блистательно, ну просто глаз не оторвать. Уже потом, гораздо позднее, Алина спросила у Алекса: «Тогда, в театре, ты заметил, что актёр, игравший Глумова, очень похож на тебя?» - «Да, потом я увидел сходство. Но в тот момент даже не заметил. Я думал только о тебе», - последовал ответ. Впрочем, её вопрос был не совсем корректным. Во-первых, потому, что театр - это искусство перевоплощения, где лица актёров становятся подчас неузнаваемыми. Во-вторых, Игорь Васильев играл отрицательного героя. Который, по сути, не имел к Алексу - с его добротой, честностью и эмоциональной искренностью - ни малейшего отношения. 


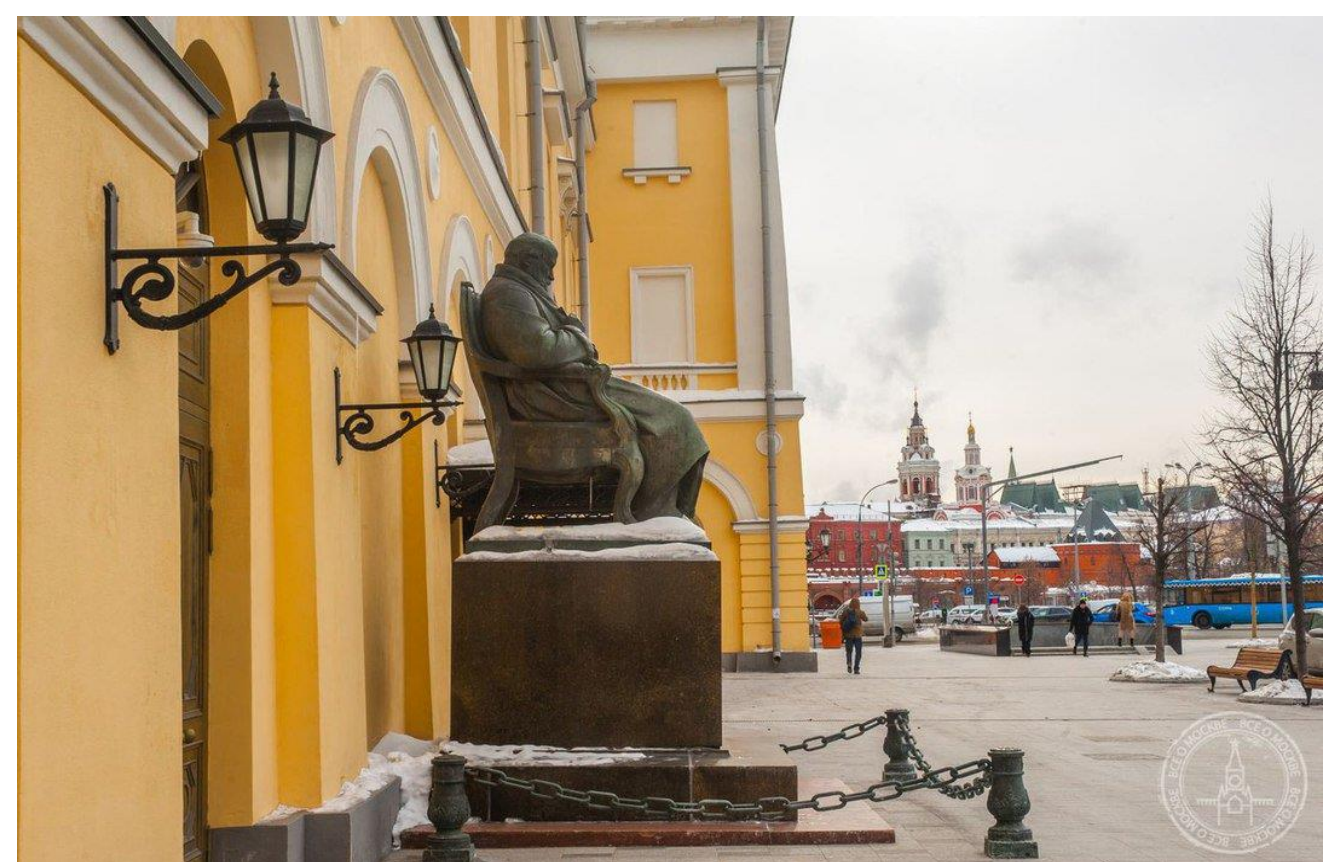

Памятник А.Н. Островскому у главного входа в Мальий театр. Театральный проезд, дом 1. Александр Николаевич Островский (1823 - 1886) - великий русский драматург, автор около пятидесяти пьес о русской жизни, премьера которых состоялась на сцене Малого театра.

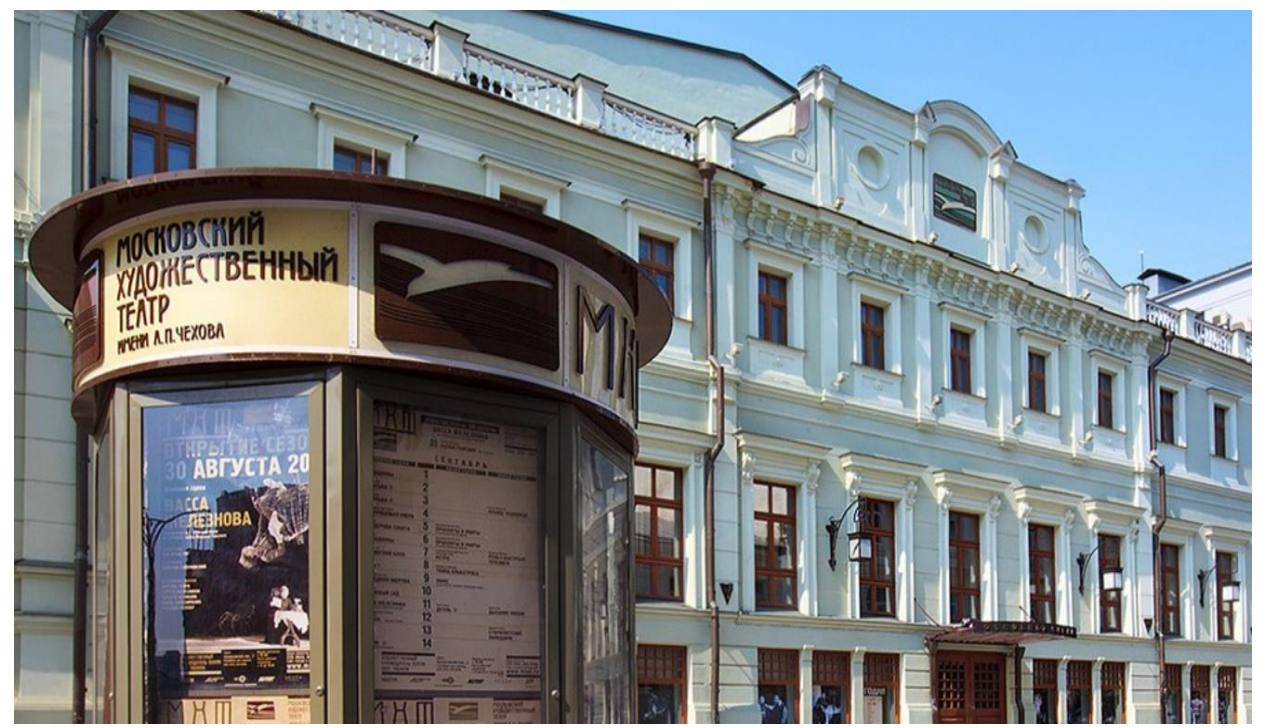

МХТ имени А.П. Чехова. Москва, Камергерский переулок, дом 3.

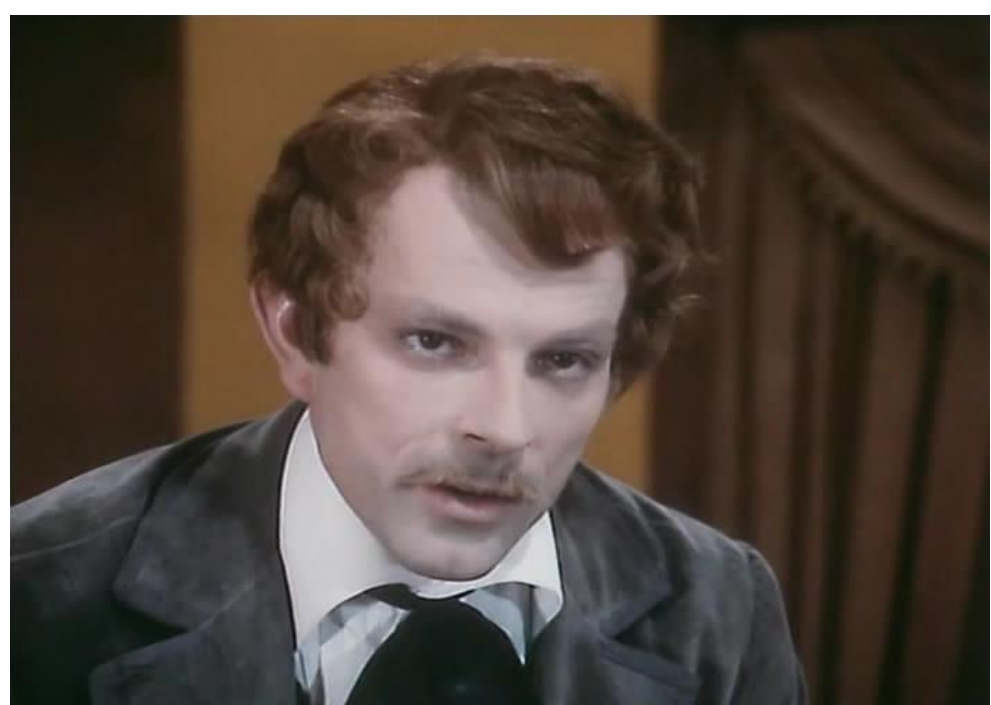


Игорь Васильев (1938 - 2007) в роли Глумова в фильме-спектакле «На всякого мудреца довольно простоты» (режиссёр - Виктор Станицын). Артист Художественного театра, сочетающий в себе большое дарование, мужское обаяние и особый тембр голоса, по которому Игоря Васильева сразу можно узнать даже по радио. Актёр запомнился зрителям множеством талантливо сыгранных ролей в театре и кино. Это Чанс Уэйн в спектакле «Сладкоголосая птица юности» по одноимённой пьесе Теннесси Уильямса - сначала во МХАТе имени Горького, (в Московском художественном академическом театре СССР имени Максима Горького), а затем в МХТ имени А.П. Чехова; Лестер в спектакле «Мария Стюарт» по одноимённой драме Ф. Шиллера; Мозгляков в спектакле «Дядюшкин сон» по одноимённой повести Ф.М. Достоевского; Зилов в спектакле «Утиная охота» по одноимённой драме А.В. Вампилова, - всего не перечислить. Егора Глумова в комедии А.Н. Островского он тоже играл просто блестяще. Персонаж-циник с «говорящей фамилией» выглядел в его исполнении потрясающе убедительным. Фамилия персонажа связана по значению с глаголом «глумиться», то есть насмехаться, словесно издеваться над кем-либо.

Алекс был на десять лет старше Алины. Оказалось, что в Москве он первый раз. Окончил Мэрилендский университет в Колледж-Парке и получил диплом магистра-филолога, основная специальность - русский язык. Это один из известных университетов США, где можно получить различные учёные степени в области русского языка и литературы [9]. Преподавал в школе. А сейчас проходил стажировку в МГУ имени М.В. Ломоносова и жил в общежитии Университета. Кумиром Алекса был Л.Н. Толстой. И не только в литературном отношении, но и как человеческая индивидуальность.
Отношения продолжались около двух лет. Встречались почти каждый день. Алекс никогда не говорил «Если ты хочешь меня видеть, то я приду сегодня», а всегда «Я сегодня приду, потому что очень хочу тебя видеть». В каком театре Москвы они только не побывали тогда, включая Большой, Театр на Таганке, Театр кукол Сергея Образцова! Не секрет, что иностранцу в то время было гораздо проще попасть в любой театр, чем москвичу. Вскоре Алекс уже ориентировался в Москве лучше, чем Алина. Да и в совершенствовании своего русского языка у него был видимый прогресс. Ему удалось найти работу стилиста в английской редакции одного из издательств, выпускающих книги на иностранных языках. У издательства было ведомственное жильё, где Алекс и поселился.

Он часто рассказывал Алине о Христе - посвоему, немного наивно.

Но как раз благодаря этой наивности его рассказ почему-то особенно сильно трогал душу...

Для встреч и прогулок они выбирали те же места, что и все влюблённые Москвы: памятник А.C. Пушкину на Пушкинской площади, парк Сокольники, Воробьёвы горы (тогда они назывались Ленинскими), Московский зоопарк, Ботанический сад, ВВЦ (Всероссийский выставочный центр, в те годы ВДНХ, -

Выставка достижений народного хозяйства, которую известный журналист и телеведущий Михаил Гусман образно назвал «советским Диснейлендом»). Подолгу наблюдали за плавающими утками - на Большом Пресненском пруду Московского зоопарка, у Новодевичьего монастыря, в зоне отдыха «Тропарёво». Смеялись, как дети, озвучивая друг другу общение уток: «крякря-кря» по-русски и «куэ'к-куэ'к-куэ'к» поанглийски («quack-quack-quack»).

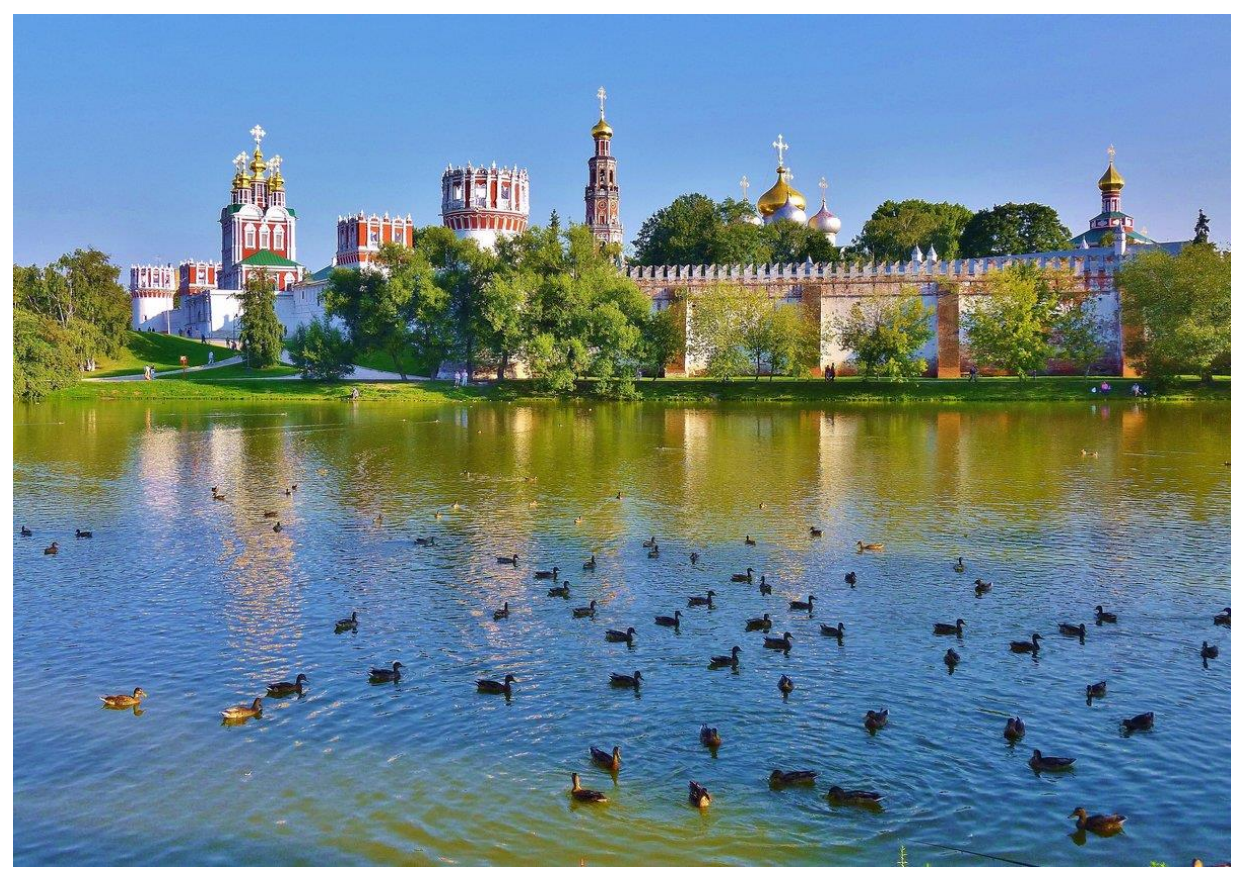

Новодевичий монастырь, Новодевичьи прудь, плавающие утки. 
Ментальный и языковой барьеры иногда мешали взаимопониманию. Но то, как они чувствовали друг друга, изумляло и подчас доходило до мистики. Алекс по натуре был психологом. Приходя в семью Алины, он по выражению её лица всегда точно прочитывал, что у них случилось. А она видела вещие сны о нём. Вот один из них.

Они ссорились, как все влюблённые, - чаще всего по пустякам. Алина знала: во-первых, Алекс давно бросил курить; во-вторых, у него нет пальто, а только куртка. Однажды после ссоры она видит такой сон. Алекс в сером пальто выходит из дверей станции метро «Кропоткинская» и закуривает. Когда Алина рассказала ему свой сон, он подтвердил: всё так и было, вплоть до мельчайших деталей. Оказывается, после ссоры он сильно разволновался и вновь взялся за сигарету. А пальто себе купил, чтобы хоть как-то успокоиться и быть похожим на русских мужчин. Он не поверил её рассказу, решив, что в тот момент она просто наблюдала за ним со стороны. Потом Алина не раз видела на нём это пальто.

В квартире у Алины на Юго-Западе Москвы Алекс всегда появлялся с букетом гвоздик, коробкой дефицитных шоколадных конфет и книгами «возвращённой литературы», которые в те годы начали активно издаваться. Это роман М.А. Булгакова «Мастер и Маргарита», проза Б.Л. Пастернака, А.П. Платонова и многое другое. Иногда он приходил ещё и с забавными мягкими игрушками. Их обожала не только Алина, но и Аннушка, её мама. Она относилась к избраннику дочери с большой теплотой. Чувствуя это, он тоже бесконечно симпатизировал ей. Отец, Григорий Андриянович, был более сдержан. Но в принципе их с Алексом отношения тоже складывались неплохо. Да и в целом во времена «перестройки» отношение общества к бракам с иностранцами было уже достаточно лояльным.

Алекс принёс справку из посольства США, что он не состоит в браке. И через три месяца знакомства они с Алиной отправились подавать заявление в Грибоедовский ЗАГС (орган записи актов гражданского состояния) Москвы, где регистрировали браки с иностранными гражданами. Здесь, кстати, зарегистрировали свой брак Владимир Высоцкий и Марина Влади: наш всенародно признанный поэт, актёр, бард и знаменитая французская актриса русского происхождения.

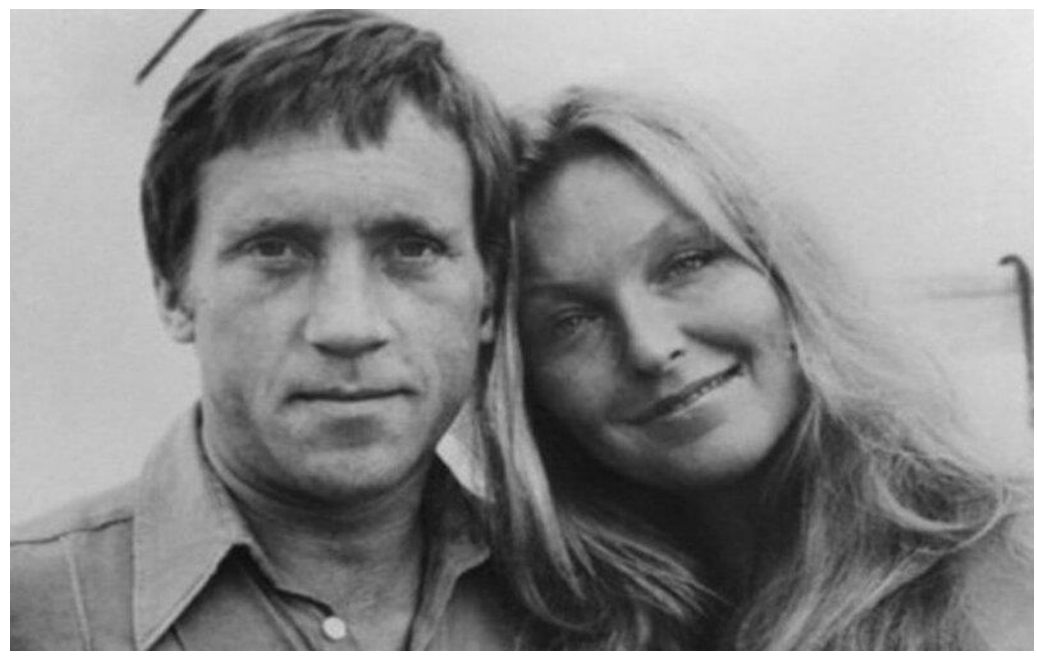

Владимир Высоцкий и Марина Влади.

Там Алекс и Алина высидели четырёхчасовую очередь. А когда попали, наконец, в долгожданный кабинет, то документы у них не приняли, так как не хватало какой-то справки, - кажется, из домоуправления.

Влюблённые собирались снова пойти в ЗАГС. Но у отца Алины случился обширный инфаркт. Мама не находила себе места и постоянно плакала. Алина тоже очень сильно переживала. В течение месяца они с Алексом каждый день навещали отца в больнице. Ехать туда было довольно долго: от метро «Беляево» до метро «Каширская», а потом ещё двадцать минут на автобусе. Низкий поклон молодым тогда ещё врачам, сумевшим, благодаря эффективной методике и человеческой отзывчивости, вытащить Григория Андрияновича ветерана Великой Отечественной войны - из тяжелейшего инфаркта. После этого отец прожил ещё 27 лет!

...А потом у Алекса в Америке внезапно умер отец. Алекс улетел на родину и звонил оттуда чуть ли не каждый день, несмотря на астрономическую стоимость телефонных переговоров. Чувство не ушло, но как-то без слов уже стало понятно, что они расстаются навсегда.

Конечно, можно винить во всём житейские причины. Например, ту, что

Алекс был вегетарианцем. В те годы это действительно превращалось в серьёзную проблему. Ассортимент продуктов для вегетарианской кухни в Москве был значительно скромнее, чем сегодня. Хотя Аннушка была отменной кулинаркой и старалась, как могла, изобретая для жениха дочери всяческие блюда, даже из обыкновенной картошки. Частенько 
выручало Алекса и московское мороженое, одно из лучших в мире (многие иностранные студенты это подтвердят). И апельсиновый сок. Тогда в столице его можно было найти почти в каждом овощном магазине или в торговой палатке.

Иногда тяжёлые обстоятельства жизни неожиданно оказываются бок о бок со смешными. В том же районе, где лечили отца от инфаркта, находилась (она и сейчас там находится) психиатрическая больница №15. Однажды, когда у метро Каширская они с Алексом покупали в палатке апельсиновый сок для отца, Алина, имея в виду свежесть продукта, уточнила у продавщицы:
«Скажите, пожалуйста, а сок нормальный?» Продавщица за словом в карман не полезла и ответила так: «Не знаю. По крайней мере, в пятнадцатую больницу его ещё не возили». После этих слов они расхохотались так, что даже пропустили свой автобус. Потом эта фраза стала у них при'сказкой. При разногласиях они в шутку говорили друг другу: «Тебя надо отвезти туда, куда ещё не возили апельсиновый сок!»

Но не будем занижать планку и попробуем взглянуть на отношения иначе - с философской и онтологической точки зрения.

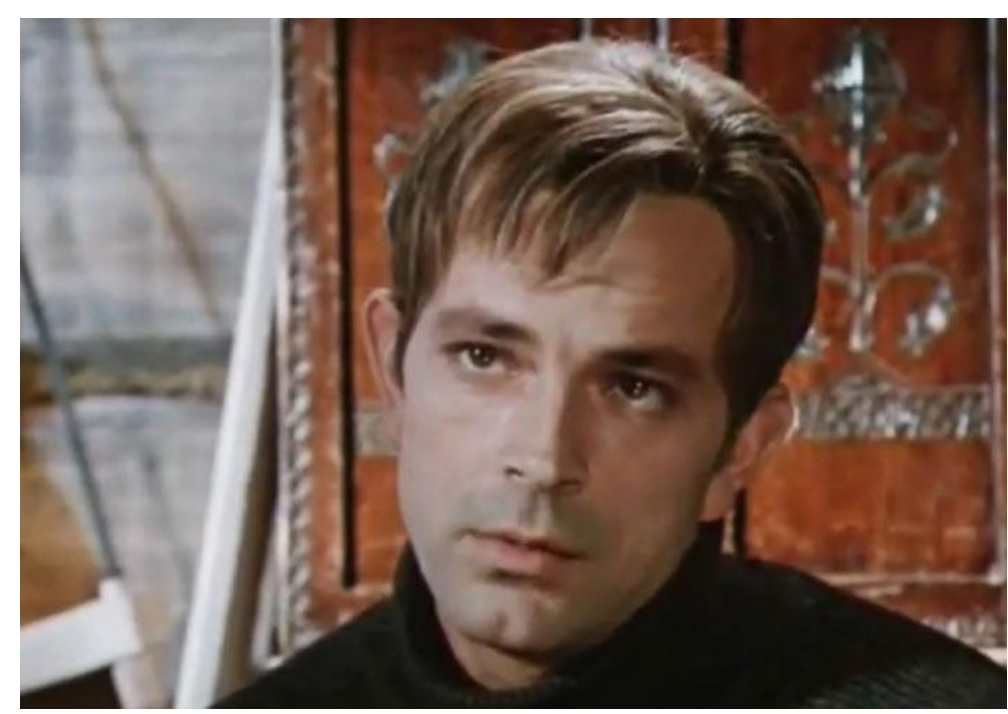

Народный артист Российской Федераџии Игорь Васильев в молодости.

Даже их имена звучали как единая музыкально-поэтическая фраза: «Алекс и Алина»... И всё же они расстались.

Когда «он» и «она» разбегаются из-за полного разочарования

друг в друге, то всё понятно. Но почему люди навсегда расстаются даже в тех случаях, когда понимают, что до кончиков волос созданы друг для друга? А именно так чаще всего бывает в первой любви. Нет ответа на этот вопрос. Но даже если бы он был, то, вероятно, не существовало бы не только такой темы в литературе, но и само'й первой любви. «Вот и прекрасно! - скажут многие. - Зачем она нужна, если приходит как безоговорочная вера в осуществимость счастья, а заканчивается глубокой печалью? И вариантов этой печали такое же количество, как звёзд во Вселенной». Но почему же тогда из века в век, с одержимой настойчивостью писатели всех стран и континентов изображают бесконечное многообразие первого чувства?
Может, потому, что у души, если она растёт и развивается, как и у тела, тоже есть переходный возраст? От детского безмятежного ощущения радости бытия к пониманию того, что жизнь не только даёт, но и отнимает. Причём отнимает самое дорогое, самое любимое. Наверное, урок первой любви преподаётся человеку для того, чтобы он научился переживать утраты, не потеряв самого себя. В некоторых литературных шедеврах например, в романе И.-В. Гёте «Страдания юного Вертера», в повести И.А. Бунина «Митина любовь», - первое чувство заканчивается экстремально трагически, гибелью главных героев. Но даже в этих произведениях есть мощный авторский посыл к читателям: держитесь, друзья, не поддавайтесь неблагоприятным обстоятельствам. И пусть первая любовь сделает ваши души сильнее и мудрее. Даже если она оканчивается разлукой. 


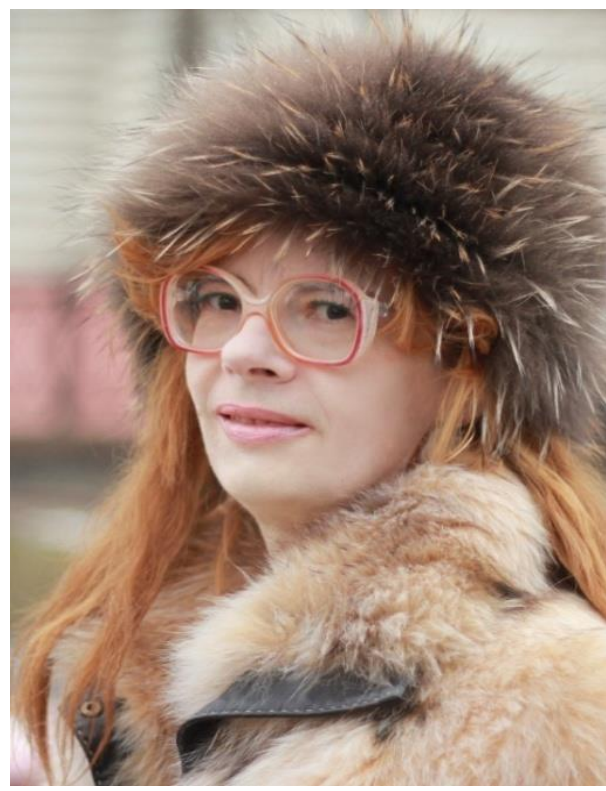

Автор новелльв в цеентре Москвы. Февраль 2014 года.

Фото из семейного архива.

Социокультурное послесловие. Пять кулинарных рецептов из блокнота Аннушки.

«Рецепт первый: картофельные пирожки с грибами.

1 килограмм картофеля, 2 луковицы, 2 яйца, 1/2 стакана панировочных сухарей.

Грибы пережарить с луком на растительном масле.

Картофель натереть на мелкой тёрке. В эту массу добавить яйца и панировочные сухари, всё перемешать и сделать тесто. Тесто раскатать на шарики и сделать из них пирожки, начинённые грибами и луком. Выпекать в духовке 25-30 минут. («Пережарить» здесь означает «немного пожарить». - Примечание автора новеллы.)

Рецепт второй: витаминный салат.

350 граммов яблок без кожицы и семян, 350 граммов помидоров, 200 граммов огурцов, 150 граммов моркови, 200 граммов салатного сельдерея, 150

граммов слив или вишни без косточек, 50 граммов сметаны, 30 граммов сахарной пудры, соль и перец по вкусу.

Овощи (кроме помидоров) нарезать соломкой толщиной по 2-3 миллиметра, а помидоры и сливы - дольками. Всё перемешать, добавить

сметану, сахарную пудру, соль, перец; а если имеется, ещё сок $1 / 4$ лимона.

Подавать к столу горкой в салатнике. Можно украсить сверху продуктами, входящими в состав салата.

Рецепт третий: рис с тыквой.

0,5 килограмма тыквы, 1,5 стакана риса, 2 сладких яблока, 1 айва, 0,5 стакана изюма, 0,5 стакана растопленного сливочного масла.

Тыкву мелко нарезать и положить на дно чугунной или эмалированной гусятницы, предварительно смазав дно маслом. Фрукты нарезать, добавить изюм и всё перемешать. Затем положить на тыкву 1/3 часть всего риса, а на него - так же слоем 1/2 часть фруктов, потом опять рис и опять фрукты, последний слой - рис. Вылить в гусятницу оставшееся масло и залить всё подсоленной водой так, чтобы верхний слой риса закрылся на полсантиметра. Варить 40-45 минут на тихом огне. (Варить на тихом огне - варить на очень слабом, медленном огне, - имеется в виду варка на газовой плите. - Примечание автора новеллы.)

Рецепт четвёртый: яблочный пирог.

1 килограмм яблок, 1 стакан сахарного песка, $1 / 4$ стакана муки, 3/4 стакана манки, 2 яйца, панировочные сухари, немного соли.

Яблоки нарезать дольками. Остальные продукты (кроме панировочных сухарей) смешать и сделать тесто (должна получиться вязкая, тягучая масса). Взять «чудо», густо смазать его сливочным маслом, густо посыпать панировочными сухарями. Постепенно залить «чудо» тестом, а сверху положить яблоки. Поставить «чудо» в духовку и выпекать 40 минут или около часа». (1. Слово «чудо» здесь обозначает специальную сковородку без ручки. C её внутренней стороны от центра до верхнего края, а затем огибая его снаружи, прикреплена металлическая тонкая полоска, которую можно крутить рукой вокруг сковородки. Когда пирог испёкся и его уже вытащили из духовки, то с помощью этой полоски он легко отделяется от дна сковородки. 2. Манка - манная крупа. - Примечание автора новеллы.)

Рецепт пятый: лимонный торт.

50 граммов дрожжей, 200 граммов сливочного масла, полстакана молока или воды, 2-3 стакана муки, полтора стакана сахарного песка, один лимон, немного соли.

Дрожжи растереть с одной столовой ложкой сахарного песка. Масло размягчить и растереть с дрожжами. Добавить молоко, муку, соль и сделать тесто (оно получится плотным). 
Начинка: один лимон, сняв половины цедры, натереть на мелкой тёрке. Добавить полтора стакана песка и хорошо перемешать. Раскатать половину теста, положить начинку и закрыть вторым листом теста, по краям тесто защипить. Выпекать в духовке около часа. Когда торт будет готов, посыпать его сахарной пудрой и в горячем виде разрезать на ромбики, не нарушая общего вида».

\section{Фотографии из Интернета}

Наталья Гундарева в фильме «Аэлита, не приставай к мужчинам».

Аэлита, не приставай к мужчинам онлайн смотреть бесплатно, ф

Sovetskoevideo.net Аэлита, не приставай к мужчинам.

https://sovetskoevideo.net/uploads/posts/201404/1396630618_aelita-ne-pristavay-kmuzhchinam.3.jpg

Татьяна Доронина в спектакле «Аэлита».

Юбилей Татьяны Дорониной: "русской Мэрилин Монро" исполняется

yarcenter.ru Татьяна Доронина в роли Аэлиты.

Юбилей Татьяны Дорониной: "русской Мэрилин Монро" исполняется 85 лет

12 Сентября $2018 \bullet$ КП-Ярославль

https://s12.stc.all.kpcdn.net/share/i/4/1565435/wx 1080.jpg

http://yarcenter.ru/articles/culture/yubiley-

tatyany-doroninoy-russkoy-merilin-monro-

ispolnyaetsya-85-let/

Владимир Высоцкий и Марина Влади.

Влади Марина и Высоцкий В.С.

Димитр Без фото Валерия Плотникова не обходился ни один советский, если можно так назвать, глянцевый журнал.Валерий Плотников родился 20 октября 1943 года в эвакуации,

месяц назад

https://yandex.ru/collections/card/5e0d3212a4ce8 e4d408df570/

Член Союза писателей России, Народный артист Российской Федерации

Олег Митяев с супругой Мариной Есипенко Народной артисткой России, ведущей актрисой Государственного академического театра имени Евгения Вахтангова.

С супругой Мариной Есипенко. - Гольфстрим

Митяев-олег.рф С супругой Мариной Есипенко. Опубликовал: Любовь

$\mathrm{http}: / /$ митяев-олег.pф/wp-

content/uploads/2015/02/aW1hZ2U6MjQxMTk5Ny8

vaW1hZ2U6MjQxMTk5Nw.jpg (1968).

Сцена из спектакля «Варшавская мелодия»

Священнодействуй или убирайся вон!

Newtimes.ru

Спектакль "Варшавская мелодия". \#ЮБИЛЕЙ \#ТОЛЬКО НА САЙТЕ

«Священнодействуй или убирайся вон!» 21.10.2014 | №34 от 30.10.14

Материал

Старовойтенко.
https://newtimes.ru/upload/medialibrary/188/TA

SS_458341.jpg

Современный спектакль «Варшавская мелодия» в Театре на Малой Бронной.

Даниил Страхов. Фотографии со спектаклей. "Варшавская мелодия»

Dstrahov.com "Варшавская мелодия". Фотограф: Владимир Кудрявцев (09.03.2017).

http://www.dstrahov.com/foto/Varshavskaya_me lodia/Kudryavtsev_2017/VM_1017_Kudryavtsev/56.j pg

Кадр из фильма «Василий и Василиса».

Во власти гордыни. О рассказе В. Г. Распутина "Василий и Василиса»

Mariamagdalina.ru

Русская Православная церковь

Ростовская-на-Дону епархия

Мария Магдалина

Официальный сайт прихода святых Жен Мироносиц города Ростова-на-Дону

015/03/18 Член Союза писателей России Сергей Прокопьев

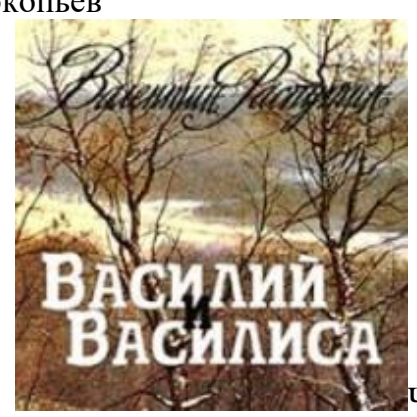

Распутин. «Василий и Василиса» Клуб православных литераторов «Омилия» (http://omiliya.org/) Использованы кадры из фильма Ирины Поплавской «Василий и Василиса». Мосфильм, 1981 г.

http://mariamagdalina.ru/wpcontent/uploads/2015/03/dec03da946dc.jpg

Юный Иван Бунин, будущий лауреат Нобелевской премии в области литературы, и его первая любовь Варвара Пащенко.

Иван Алексеевич Бунин. Слово о писателе. "Тёмные аллеи"

Videouroki.net ...но вопреки их воле девушка ушла из дома

Конспекты / Литература / 9 класс / Русская литература 9 класс ФГОС /

Иван Алексеевич Бунин. Слово о писателе. «Тёмные аллеи»

Урок 56. Русская литература 9 класс ФГОС На этом уроке мы поговорим о жизненном и творческом пути великого русского писателя и поэта

Ивана Алексеевича Бунина. Проследим историю создания книги «Тёмные аллеи». Конспект урока "Иван Алексеевич Бунин. Слово о писателе. «Тёмные аллеи»" Лицензия на осуществление образовательной деятельности №5251 от 25.08.2017 г. Подробнее 
https://fsd.videouroki.net/products/conspekty/rusl it9/56-ivan-alekseevich-bunin-slovo-o-pisateletyomnye-allei.files/image002.jpg

https://videouroki.net/video/56-ivan-alekseevichbunin-slovo-o-pisatele-tyomnye-allei.html

Народная артистка Российской Федерации Татьяна Васильева.

Актриса Татьяна Васильева - Российская газета Rg.ru

Актриса Татьяна Васильева. (c) 1998-2020 ФГБУ «Редакция «Российской газеты»

https://cdnimg.rg.ru/i/gallery/167ece96/5_95bdf1 84.jpg

Татьяна Васильева в фильме «Дуэнья».

Фильм "Дуэнья", СССР, 1978: когда смотреть по ТВ? Comboplayer.ru

Фильм Дуэнья. Фильм Дуэнья Комедия 16+ передач:

Последнее появление "Дуэнья" в программе

\section{Россия $\mathcal{K}$}

Россия К

Смотреть онлайн

https://www.comboplayer.ru/static/video_images/c2e ${ }^{2}$ 8e0/c2e8e0f3f7f7677d.jpg

Татьяна Васильева и Евгений Леонов в фильме «Дуэнья».

Фильм "Дуэнья", СССР, 1978: когда смотреть по TB? comboplayer.ru

Фильм Дуэнья.

Фильм Дуэнья Комедия 16+

Последнее появление "Дуэнья" в программе передач:

\section{РосСия $\mathcal{K}$}

Россия К

Смотреть онлайн

https://www.comboplayer.ru/static/video_images/46c/ 684/46c684c3c3cbdbc2.jpg

Татьяна Васильева в спектакле «Ревизор».

Татьяна Васильева (Татьяна Ицыкович) фотографии -

M.kino-teatr.ru Татьяна Васильева - "Ревизор" (1982). Фото добавил посетитель omela http://m.kino-teatr.ru/acter/album/698/519937.jpg

Татьяна Васильева в фильме «Самая обаятельная и привлекательная».

Самая обаятельная и привлекательная трейлер фильм в $1080 \mathrm{~h}$

Fullhdfilm.ru Смотреть онлайн кадры и актеров к фильму

https://cepia.ru/images/u/pages/5154/samayaobayateljnaya-i-privlekateljnaya-8.png
«Мамочка, я тебя люблю!»

Пин от пользователя Lynda Jensen на доске Family Goals Мать

br.pinterest.com Пин от пользователя Lynda Jensen на доске Family Goals | Мать и дочь, Детские наряды и Ми...

Источник: kseniablog.tumblr.com

Ksenia http://kseniablog.tumblr.com/

Стиль

Любовная ПараМалыш МальчикДетский

https//br.printerest.com/annapogromska/детскийстиль/

https://i.pinimg.com/736x/fa/fb/09/fafb09500921 85b332d00605a1b25c67--mother-daughter-fashion-

mommy-and-me.jpg

У Большого театра в новогодние праздники.

Вести.Ru: На фасаде Большого театра в Москве в рождественски Vesti.ru

На три дня фасад Большого театра превратится НовостиОбщество

Все видео этой рубрики

5 января 201515:50 На фасаде Большого театра

в Москве в рождественские дни появятся "ангелы" https://cdn-st1.rtr-vesti.ru/p/xw_1044740.jpg

Народные артисты СССР Екатерина Максимова и Владимир Васильев в балете П.И. Чайковского «Щелкунчик».

Щелкунчик / Культурное наследие / Бэйбики. Куклы фото. Одежд Babiki.ru

AndreTcoу Шопик AndreTcoy 31 октября 2016, 22:18 Щелкунчик

Разное $\rightarrow$ Культурное наследие

https://radikal.ru/lfp/s05.radikal.ru/i178/1611/24/

890738dca319.jpg/htm

https://babiki.ru/blog/kulturnoe-

nasledie/79022.html

Сергей Зверев.

4 знаменитых мужчины, которые регулярно делают макияж sm-new

Sm-news.ru Сергей Зверев.

11 июля 201917:073наменитости

https://sm-news.ru/wp-

content/uploads/2019/03/19/sergej-zverev.jpg

Памятник А.Н. Островскому у входа в Малый театр.

На квартире в Твиттере: "Неслучайно в самом шентре Москвы у М

Twitter.com Неслучайно в самом центре Москвы у Малого

Наквартире

@ Nakvartire com

/Nakvartire_com/status/984431475721465858

Читать Читать@Nakvartire_com

Неслучайно в самом центре Москвы у Малого театра установили памятник А.Н. Островскому. 14 января 1853 года в его стенах зрители увидели первую постановку пьесы Александра Николаевича. В то время никто не мог подумать, что здесь поставят 46 из 47 пьес... https://t2p.pw/FkGLX7bc87

07:02 - 12 апр. 2018 г. Москва, Россия

https://twitter.com/nakvartire_com/status/984431 475721465858 
https://pbs.twimg.com/media/DalnMuCX4AAtL Ac.jpg

МХТ имени А.П. Чехова.

http://oteatre.info/wp-

content/uploads/2018/07/8440541699_3ea7a261bc_o. jpg

Oteatre.info MХТ им. А. Чехова завершил сезон предпремьерным показом спектакля Юрия Бутусова «Человек из рыбы»

МАРИЯ ФРАНЦЕВА 11 июля 2018 Ася Волошина, МХТ, Юрий Бутусов

http://oteatre.info/wpcontent/uploads/2018/07/8440541699_3ea7a261bc_o. jpg

http://oteatre.info/mht-zavershil-sezon-

spektaklem-butusova/

Игорь Васильев в роли Глумова в фильме-спектакле «На всякого мудреца довольно простоты».

Киноклуб "Феникс" - На всякого мудреца довольно простоты (1976)

Fenixclub.com Глумов - Игорь Васильев

МХАТ им.М.Горького

Творческое объединение "Экран"

Год выпуска: 1976

Жанр: комедия

Автор: Александр Островский

Режиссер: Виктор Станицын

http://fenixclub.com/uploads/33602/img-43681369607cefec.jpg

Новодевичий монастырь, Новодевичьи пруды, плавающие утки.

Yandex.com Новодевичий монастырь.

Утки на Новодевичьем пруду Парк у Новодевичьего монастыря фото

kuznetsova glascha Вечером... \#конкурс \#лето \#пруд \#утки Expand

Uploaded 2 years ago

https://avatars.mds.yandex.net/getpdb/367895/775f8b0e-bd9b-47b5-96f152675e326f1e/s1200 Favorite images Yandex.Collections

В. Высоцкий и М. Влади.

Владимир Высоцкий и Марина Влади Благо Дарю

Благо-дарю.укр

Владимир Высоцкий и Марина Влади:

13.05 .2018

A B T O P :

Y A R O V Y I Владимир Высоцкий и Марина Влади: трагический сценарий прекрасной любви https://благо-

дарю.укр/blog/2018/05/13/\%D0\%B2\%D0\%BB\%D0

$\% \mathrm{~B} 0 \% \mathrm{D} 0 \% \mathrm{~B} 4 \% \mathrm{D} 0 \% \mathrm{~B} 8 \% \mathrm{D} 0 \% \mathrm{BC} \% \mathrm{D} 0 \% \mathrm{~B} 8 \% \mathrm{D} 1 \% 8$ $0-$

$\% \mathrm{D} 0 \% \mathrm{~B} 2 \% \mathrm{D} 1 \% 8 \mathrm{~B} \% \mathrm{D} 1 \% 81 \% \mathrm{D} 0 \% \mathrm{BE} \% \mathrm{D} 1 \% 86 \% \mathrm{D}$ $0 \% \mathrm{BA} \% \mathrm{D} 0 \% \mathrm{~B} 8 \% \mathrm{D} 0 \% \mathrm{~B} 9-\% \mathrm{D} 0 \% \mathrm{~B} 8$

$\% \mathrm{D} 0 \% \mathrm{BC} \% \mathrm{D} 0 \% \mathrm{~B} 0 \% \mathrm{D} 1 \% 80 \% \mathrm{D} 0 \% \mathrm{~B} 8 \% \mathrm{D} 0 \% \mathrm{BD} \%$ $\mathrm{D} 0 \% \mathrm{~B} 0$

\%D0\%B2\%D0\%BB\%D0\%B0\%D0\%B4\%D0\%B8/

https://obaldela.ru/wp-

content/uploads/2017/05/2411.jpg

Игорь Васильев в молодости.
Игорь Васильев - биография, информация, личная жизнь, фото,

stuki-druki.com Игорь Васильев.

https://stuki-druki.com/biofoto1/Igor-Vasiljev-

Inzhener-Pronchatov.jpg

\section{Список использованной литературы}

1. Брылева Н.А. Музыкальная и вербальная коммуникации в культуре. / Журнал Вестник Красноярского государственного аграрного университета, Область наук: Искусствоведение. 2007. https://cyberleninka.ru/article/n/muzykalnaya-iverbalnaya-kommunikatsii-v-kulture

2. Брылина И.В. Философия русского эроса как социокультурный феномен. / Евразийство и мир 3/2014. - C.65-80.

3. Бунин И.А. Митина любовь. / Бунин И.А. Собрание сочинений в 6-ти т. Т.4.- М.: «Художественная литература», 1988. - 703 с. - Т.4. Произведения 1914-1931. / Редколлегия: Ю.Бондарев, О.Михайлов, В. Рынкевич. Статьяпослесловие и комментарий А. Саакянц. - М.: «Художественная литература», 1988. - 703 с.

4. Васильева Татьяна Григорьевна. Материал из Википедии - свободной энциклопедии. https://ru.wikipedia.org/wiki/\%D0\%92\%D0\%B0\%D1 $\% 81 \% \mathrm{D} 0 \% \mathrm{~B} 8 \% \mathrm{D} 0 \% \mathrm{BB} \% \mathrm{D} 1 \% 8 \mathrm{C} \% \mathrm{D} 0 \% \mathrm{~B} 5 \% \mathrm{D} 0 \% \mathrm{~B}$ 2\%D0\%B0,_D0\%A2\%D0\%B0\%D1\%82\%D1\%8C $\% \mathrm{D} 1 \% 8 \mathrm{~F} \% \mathrm{D} 0 \% \mathrm{BD} \% \mathrm{D} 0 \% \mathrm{~B} 0 \% \mathrm{D} 0 \% 93 \% \mathrm{D} 1 \% 80 \%$ D0\%B8\%D0\%B3\%D0\%BE\%D1\%80\%D1\%8C\%D0 $\% \mathrm{~B} 5 \% \mathrm{D} 0 \% \mathrm{~B} 2 \% \mathrm{D} 0 \% \mathrm{BD} \% \mathrm{D} 0 \% \mathrm{~B} 0 \#$ cite_note- 12

5. Вышеславцев Б.П. Этика преображённого Эроса. / Вступ. ст., сост. И коммент. В.В. Сапова. Москва: Республика, 1994. - 368с. - (Б-ка этической мысли).

6. Кондрашова Н.В., Кокошникова Н.А. Русский язык как иностранный. Разговорные темы: Учебное пособие - Санкт-Петербург: Университет ИТМО, 2016. - 61 c.

7. Котелевская Э.И. Характеристика любовного общения и жанрообразующие

исследовательские топосы. Журнал Политематический сетевой электронный научный журнал Кубанского государственного аграрного университета 2015 BAK AGRIS

https://cyberleninka.ru/article/n/harakteristikilyubovnogo-obscheniya-i-zhanroobrazuyuschieissledovatelskie-toposy

8. «Российский радиоуниверситет». 28 января 2019 года. Откуда есть пошла Беларусь? Программу ведут Анна Дворецкова и Дмитрий Конаныхин <..> Беседуем с историком, кандидатом исторических наук, доцентом кафедры истории южных и западных славян исторического факультета МГУ имени М. В. Ломоносова Юрием Аркадьевичем Борисёнком. 81830

https://www.radiorus.ru/brand/63253/episode/20

9. Русский язык в США «РУССКИИИ ЯЗЗЫК В США»

https://lingvostranoved.livejournal.com/479.html 
10. Сутормин В.В. Интерес к противоположному полу в студенческом возрасте: социальные и личностные аспекты. / Вестник ТГУ, выпуск 3 (47), 2007. - С.171-176.

11. Тургенев И.С. Воробей / Тургенев И.С. Полное собрание сочинений и писем в тридцати томах. Москва: Наука, 1982. Т. 10. С. 142.

(C) Электронная публикация — РВБ, 20102020. Версия 2.0 от 22 мая 2017 г. 31.htm

https://rvb.ru/turgenev/01text/vol_10/02senilia/02

12. Улица Больша́я Дми́тровка (в начале 1920х годов - улица Эже́на Потье́, в 1937-1993 годах - Пу́шкинская улица) - улица в Тверском районе Центрального административного округа города Москвы. Проходит от улицы Охотный Ряд до Страстного бульвара / Улица Большая Дмитровка
Материал из Википедии - свободной энциклопедии.

13. Успенский П.Д. Искусство и любовь. / Русский Эрос, или Философия любви в России / Сост. и авт. вступ. ст. В.П. Шестаков; Коммент. А.Н. Богословского. - Москва: Прогресс, 1991. -448 с.: ил. - С. 221-231.

https://ru.wikipedia.org/wiki/\%D0\%A3\%D0\%B B\%D0\%B8\%D1\%86\%D0\%B0_\%D0\%91\%D0\%BE \%D0\%BB\%D1\%8C\%D1\%88\%D0\%B0\%D1\%8F_\% D0\%94\%D0\%BC\%D0\%B8\%D1\%82\%D1\%80\%D0 $\% \mathrm{BE} \% \mathrm{D} 0 \% \mathrm{~B} 2 \% \mathrm{D} 0 \% \mathrm{BA} \% \mathrm{D} 0 \% \mathrm{~B} 0$

14. Юнгер Ф.-Г. Язык и мышление. Friedrich Georg Jünger. Sprache und Denken. / Перевод с немецкого К.В. Лощевского. - Слово сущее. Том 58. - Санкт-Петербург, «Наука», 2005. - 300 с. 